Прегледни чланак

doi:10.5937/zrpfns54-28441

Jovana D. Vojvodić, Ph.D. Student

University of Novi Sad

Faculty of Law Novi Sad

joja994ns@gmail.com

\title{
RESPECT OF THE ARTICLE 8 OF THE EUROPEAN CONVENTION FOR THE PROTECTION OF HUMAN RIGHTS AND FUNDAMENTAL FREEDOMS IN THE RECENT CASE LAW OF THE EUROPEAN COURT OF HUMAN RIGHTS
}

Abstract: Private life, family life, home and correspondence represent some of the most intimate and significant aspects of human life. The focus of this paper is an analysis of the right to respect for private life, family life, home and correspondence, as the elements of the protection of the Article 8 of the European Convention for the Protection of Human Rights and Fundamental Freedoms. The analysis was primarily conducted through research and interpretation of the European Court of Human Rights recent case law, whereby, some of the cases of the highest importance as well as the case of the Republic of Serbia as a respondent state, were specially observed.

Keywords: European Convention for the Protection of Human Rights and Fundamental Freedoms, European Court of Human Rights, Article 8, private life, family life, home, correspondence.

\section{THE INTRODUCTION}

The main topic of this paper is a research of the concepts of private life, family life, home and correspondence in recent case law of the European Court of Human Rights (in further text "the Court"), with special review on the need for more efficient protection of the mentioned rights by the signatory states to the European Convention for the Protection of Human Rights and Fundamental Freedoms (in further text "the Convention"). The reason for choosing this subject lies in the fact that rights protected by the Article 8 occupy extremely important positions 
in the Convention, thus we can say they are in its protection focus. The first part of the first chapter of this paper refers to the explanation of the concepts of private life, family life, home and correspondence. The second part of the first chapter deals with limitations of the Article 8 rights, set out in Paragraph two of the mentioned Article. The second chapter is the main area of this paper, and its aim is to research Court's new provisions in the means of usage range of the Article 8 of the Convention. The first part of the second chapter represents the statistical review of all the cases of violation establishments of the Article 8 by the Court during the year of 2019, while the second part contains short overview of certain cases specified as "key cases." Furthermore, the third part describes the sole case in which the Republic of Serbia was the respondent case. At the end, conclusions were drawn.

\section{THE NOTION AND THE RESTRICTIONS OF THE ARTICLE 8 OF THE CONVENTION}

\subsection{The main principals of the application of the Article 8 of the Convention}

The Article 8 of the Convention states:

1. Everyone has the right to respect for his private and family life, his home and his correspondence.

2. There shall be no interference by a public authority with the exercise of this right except such as is in accordance with the law and is necessary in a democratic society in the interests of national security, public safety or the economic well-being of the country, for the prevention of disorder or crime, for the protection of health or morals, or for the protection of the rights and freedoms of others. ${ }^{1}$

The Court's judgments have repeatedly stated that the essential object of the Article 8 is to protect the individual against arbitrary interference by public authorities. ${ }^{2}$ The wording suggests a profoundly negative 'right to be left alone,' and yet most of the case law has focused on the positive dimension of the right. ${ }^{3}$ However, it should be mentioned that the State must not only abstain from interference with right to private and family life, but it must also protect individuals from infringements of the right that are attributable to others. ${ }^{4}$ Despite the dis-

${ }^{1}$ European Convention for the Protection of Human Rights and Fundamental Freedoms, European Court of Human Rights, Council of Europe, 1950, Art. 8.

${ }^{2}$ P. and S. v. Poland, no. 57375/08, no. 94, 30th of October 2012, para. 94.

${ }^{3}$ William A. Schabas, The European Convention on Human Rights: A Commentary, Oxford University Press, Oxford 2016, 366.

${ }^{4} X$ and $Y$ v. the Netherlands, app.no. 8978/80, judgment of $26^{\text {th }}$ of March 1985, para. 23; Söderman v. Sweden, app.no. 5786/08, judgment of $12^{\text {th }}$ of November 2013, para. 78; Tavll v.Turkey, app.no. 11449/02, judgment of $9^{\text {th }}$ of November 2006, para. 28; Airey v. Ireland, app.no. 6289/73, judgment of $9^{\text {th }}$ of October 1979, para. 32 . 
tinction being made between positive and negative obligations under the Article 8 , it is not always evident whether an interference results from a denial of the right or a failure of a state to provide an adequate regulatory framework. ${ }^{5}$

The Article 8 is considered to be one of the most flexible provisions of the Convention, since it has shown very adaptable to changes and applicable to a great range of situations. ${ }^{6}$ The rights protected under the Article 8 are among Convention's broadest rights in means of the usage domain. They demand special balancing between the need for the protection of human rights of the individuals and the protection of national interests of member states. ${ }^{7}$ Because of beforementioned, the Court allows member states a wide margin of appreciation reflected in two notions. Firstly, the notion of "respect" of the right to respect private and family life is not clear-cut, and its requirements will vary considerably from case to case. Furthermore, the Paragraph 2 of the Article 8 provides that the right to private and family life may be subject to restrictions. ${ }^{8}$

\subsection{Stating the concepts of private life, family life, home and correspondence}

\subsubsection{The concept of private life}

The Court has explained that 'private life' is a broad term encompassing the sphere of personal autonomy, for which is impossible to give the unique definition. ${ }^{9}$ The concept of private life implies that everyone can freely pursue the development

\footnotetext{
${ }^{5}$ Dickson v. the United Kingdom, app.no. 44362/ 04, judgment of $4^{\text {th }}$ of December 2007, para. 71; Nunez v. Norway, app.no. 55597/09, judgment of $28^{\text {th }}$ of June 2011, para. 69.

${ }^{6}$ Ivana Roagna, Protecting the right to respect for private and family life under the European Convention on Human Rights, Council of Europe human rights handbooks, Directorate General of Human Rights and Rule of Law Council of Europe, Strasbourg 2012, 11.

${ }^{7}$ Roche v. the United Kingdom, app.no. 32555/96, judgement of $19^{\text {th }}$ of October 2005, para. 157; Gaskin v. the United Kingdom app.no. 10454/83, judgement of $7^{\text {th }}$ of July 1989, para. 42; Hämäläinen v. Finland, app.no. 37359/09, judgement of $16^{\text {th }}$ of July 2014, para. 65 .

${ }^{8}$ Jean-François Akandji Kombe, Positive obligations under the European Convention on Human Rights, Council of Europe Human Right Handbook Series No. 7, Belgium 2007, 36.

${ }^{9}$ Costello-Roberts v. The United Kingdom, app.no. 13134/87, judgment of $25^{\text {th }}$ of March 1993, para. 36; Schuth v. Germany, app.no. 1620/03, judgment of $23^{\text {rd }}$ of September 2010, para. 53; Fernandez Martinez v. Spain, app.no. 56030/07, judgment of $12^{\text {th }}$ of June 2014, para. 109; Nada v. Switzerland, app.no. 10593/08, judgment of 12 ${ }^{\text {th }}$ of September 2012, para. 151; Glor v. Switzerland, app.no. 13444/04, judgment of $30^{\text {th }}$ of April 2009, para. 52; Tysiac v. Poland, app.no.5410/03, judgment of $20^{\text {th }}$ of March 2007, para. 107; Pretty v. the United Kingdom, app.no. 2346/02, judgment of $29^{\text {th }}$ of April 2002, para. 61; S. and Marper v. United Kingdom, app.no. 30562/04 and 30566/04, judgment of $4^{\text {th }}$ of December 2008, para. 66; Bensaid v. the United Kingdom, app.no. 44599/98, judgment of $6^{\text {th }}$ of February 2001, para. 47; Bărbulescu v. Romania, app.no. 61496/08, judgment of $5^{\text {th }}$ of September 2017, para. 70; Denisov v. Ukraine, app.no. $76639 / 11$, judgment of $25^{\text {th }}$ of September 2018, para. 95.
} 
of their personality and establish relationships with the outside world ${ }^{10}$ simply said - to live life with minimum od interference. ${ }^{11}$ The Court has determined that the protection of private life entails, inter alia, the protection of physical, psychological and moral integrity of an individual ${ }^{12}$ (including the protection of health ${ }^{13}$ and medical care ${ }^{14}$ ); the protection of the social identity of an individual (including the right of free choice of professional orientation and professional activities, ${ }^{15}$ name, ${ }^{16}$ nationality, ${ }^{17}$ freedom of religious choice, ${ }^{18}$ sexual identity and sexual orientation $\left.{ }^{19}\right)$; the protection of right to terminate one's own life; ${ }^{20}$ the protection of right to choose of place of living, ${ }^{21}$ personal data protection; ${ }^{22}$ the protection of

${ }^{10}$ Jehovah's Witnesses of Moscow v. Russia, app.no. 302/02, judgment of $10^{\text {th }}$ of June 2010, para. 117; Gillberg v. Sweden, app.no. 41723/06, judgment of $3^{\text {rd }}$ of April 2012, para. 66; S. and Marper v. United Kingdom, app.no. 30562/04 and 30566/04, judgment of $4^{\text {th }}$ of December 2008, para. 66; Haas v. Switzerland, app.no. 31322/07, judgment of $20^{\text {th }}$ of January 2011, para. 50; Niemietz v. Germany, app.no. 13710/88, judgment of $16^{\text {th }}$ of December 1992, p. 29; Sargsyan v. Azerbaijan, app.no. 40167/06, judgment of 16 June 2015, p. 255; Denisov v. Ukraine, app.no. 76639/11, judgment of 25 September 2018, para. 100.

${ }^{11}$ W. A. Schabas, 369.

${ }^{12}$ E.S. v. Sweden, app.no. 5786/08, judgment of $21^{\text {st }}$ of June 2012, para. 40; Von Hannover v. Germany, app.no. 40660/08, 60641/08, judgment of $07^{\text {th }}$ of February 2012, para. 95; Gillberg v. Sweden, app.no. 41723/06, judgment of $3^{\text {rd }}$ of April 2012, para. 68; Costello-Roberts v. The United Kingdom, app.no. 13134/87, judgment of $25^{\text {th }}$ of March 1993, para. 36; X and $Y v$. the Netherlands, app.no. 8978/80, judgment of $26^{\text {th }}$ of March 1985, para. 22; J. A. Kombe, 37; Loukēs G. Loukaidēs, The European Convention on Human Rights: Collected Essays, Martinus Nijhoff Publishers, Leiden 2007, 98

${ }^{13}$ Nada v. Switzerland, app.no. 10593/08, judgment of $12^{\text {th }}$ of September 2012, para. 151; Tysiac v. Poland, app.no. 5410/03, judgment of $20^{\text {th }}$ of March 2007, para. 107

${ }^{14}$ Y.F. v. Turkey, app.no. 24209/94, judgment of 22nd of July 2003, para. 33.

${ }^{15}$ Fernandez Martinez v. Spain, app.no. 56030/07, judgment of $12^{\text {th }}$ of June 2014, para. 110; Bigaeva v. Greece, app.no. 26713/05, judgment of $28^{\text {th }}$ of May 2009, para. 23; Sidabras and Džiautas v. Lithuania, app.no. 55480/00, 59330/00, judgment of $27^{\text {th }}$ of July 2004, para. 47; Niemietz v. Germany, app.no. 13710/88, judgment of $16^{\text {th }}$ of December 1992, para. 29.

${ }^{16}$ Negrepontis-Giannisis v. Greece, app.no. 56759/08, judgment of $3^{\text {rd }}$ of May 2011, para. 55; Znamenskaya v. Russia, app.no. 77785/01, judgment of $2^{\text {nd }}$ of June 2005, para. 23; Cierva Osorio de Moscoso and Others v. Spain, app.no. 41127/98, 41503/98, 41717/98, 45726/99, judgment of $28^{\text {th }}$ of October 1999

${ }^{17}$ S. and Marper v. United Kingdom, app.no. 30562/04, 30566/04, judgment of $4^{\text {th }}$ of December 2008, para. 66; Ciubotaru v. Moldova, app.no. 27138/04, judgment of 27th of April 2010, para. 49; Chapman v. the United Kingdom, app.no. 27238/95, judgment of $18^{\text {th }}$ of January 2001, para. 73-74.

${ }^{18}$ Ciubutaru v. Moldova, app.no. 27138/04, judgment of $27^{\text {th }}$ of April 2010, para. 53.

${ }^{19}$ Bensaid v. the United Kingdom, app.no. 44599/98, judgment of $6^{\text {th }}$ of February 2001, para. 47; Peck v. the United Kingdom, app.no. 44647/98, judgment of $28^{\text {th }}$ of January 2003, para. 57; Stübing v. Germany, app.no. 43547/08, judgment of $12^{\text {th }}$ of April 2012, para. 55; Dudgeon v. the United Kingdom, app.no. 7525/76, judgment of $22^{\text {nd }}$ of October 1981, para. 41.

${ }^{20}$ Haas v. Switzerland, app.no. 31322/07, judgment of $20^{\text {th }}$ of January 2011, para. 51.

${ }^{21}$ Alkaya v. Turkey, app.no. 42811/06, judgment of $9^{\text {th }}$ of October 2012, para. 30.

${ }^{22}$ Leander v. Sweden, app.no. 9248/81, judgment of $26^{\text {th }}$ of March 1987, para. 48; Amann v. Switzerland, app.no 27798/95, judgment of $16^{\text {th }}$ of February 2000, para. 69-70; Khelili v. Switzerland, 
honor and reputation; ${ }^{23}$ the protection from arbitrary interference by public authorities and seizure of property; ${ }^{24}$ the protection from noise. ${ }^{25}$

Although certain issues related to marital and parental status of citizens (such as entering into a marriage, marriage annulment, paternity proceedings, adoption proceedings) belong with the concept of family life, they also fall within the scope of protection of private life. ${ }^{26}$

\subsubsection{The concept of family life}

The protection of family life presupposes the existence of a family. ${ }^{27}$ The Court has stated that the concept of family does not only include relations by marriage. On the contrary, family exists whenever there are certain number of people between whom constant and close family relations can be determined. ${ }^{28}$ The Court has recognized the existence of family life between parents and children, spouses, ${ }^{29}$ extramarital cohabitation partners, ${ }^{30}$ siblings,,${ }^{31}$ and grandparents and grandchildren..$^{32}$ Relationship between parents and children is considered to be a fundamental element of family life. ${ }^{33}$ Any restriction of parental rights must

app.no. 16188/07, judgment of $18^{\text {th }}$ of October 2011, para. 55; M.M. v. the United Kingdom, app.no. 24029/07, judgment of $13^{\text {th }}$ of November 2012, para. 187.

${ }^{23}$ Pfeifer v. Austria, app.no. 12556/03, judgment of $15^{\text {th }}$ of November 2007, para. 38; Chauvy and Others v. France, app.no. 64915/01, judgment of $29^{\text {th }}$ of June 2004, para. 70.

${ }^{24}$ Gillan and Quinton v. the United Kingdom, app.no. 4158/05, judgment of $12^{\text {th }}$ of January 2010, para. 63.

${ }^{25}$ Moreno Gómez v. Spain, app.no. 4143/02, judgment of $16^{\text {th }}$ of November 2004, para. 9-19, 58-60; Hatton and Others v. the United Kingdom, app.no. 36022/97, judgment of $8^{\text {th }}$ of July 2003, para. 96; Oluić v. Croatia, app.no 61260/08, judgment of $20^{\text {th }}$ of May 2010, para. 45; Mileva and Others v. Bulgaria, app.no. 43449/02, 21475/04, judgment of $25^{\text {th }}$ of November 2010, para. 97.

${ }^{26}$ Dadouch v. Malta, app.no. 38816/07, judgment of $20^{\text {th }}$ of July 2010, para. 48; Rasmussen v. Denmark, app.no. 8777/79, judgment of $28^{\text {th }}$ of November 1984, para. 33; Shofman v. Russia, app.no. $74826 / 01$, judgment of $24^{\text {th }}$ of November 2005, para. 30-33; A.H. and Others v. Russia, app. no. $6033 / 13,8927 / 13,10549 / 13,12275 / 13,23890 / 13,26309 / 13,27161 / 13,29197 / 13,32224 / 13$, $32331 / 13,32351 / 13,32368 / 13,37173 / 13,38490 / 13,42340 / 13,42403 / 13$, judgment of $17^{\text {th }}$ of January 2017, para. 383.

${ }^{27}$ Marckx v. Belgium, app.no. 6833/74, judgement of $13^{\text {th }}$ of June 1979, para. 31

${ }^{28}$ Krušković v. Croatia, app.no. 46185/08, judgment of 21 $1^{\text {st }}$ of June 2011, para. 18; Kroon and Others v. the Netherlands, app.no. 18535/91, judgment of $27^{\text {th }}$ of October 1994, para. 30; K. and T. v. Finland, app.no. 25702/94, judgment of $12^{\text {th }}$ of July 2001, para. 150.

${ }^{29}$ Abdulaziz, Cabales and Balkandali v. United Kingdom, app.no. 9214/80 9473/81 9474/81, judgement of $28^{\text {th }}$ of May 1985, para. 62.

${ }^{30}$ Kroon and Others $v$. the Netherlands, app.no. 18535/91, judgement of $27^{\text {th }}$ of October 1994 , para. 30.

${ }^{31}$ A.A. v. The United Kingdom, app.no. 8000/08, judgement of $20^{\text {th }}$ of September 2011, para. 34; Mustafa and Armağan Akın v. Turkey, app.no. 4694/03, judgement of $6^{\text {th }}$ of April 2010, para. 19.

${ }^{32}$ Bronda v. Italy, app.no. 22430/93, judgement of $9^{\text {th }}$ of June 1998, para. 51.

${ }^{33}$ Bronda v. Italy, app.no. 22430/93, judgement of $9^{\text {th }}$ of June 1998, para. 51. 
be supported by sufficiently sound ${ }^{34}$ and weighty considerations in the best interests of the child, ${ }^{35}$ having in mind that the potential separation of children from their parents could cause serious, even unrepairable consequences for their relationship. ${ }^{36}$ Family life entails both relations between biological parents and their biological (legitimate or illegitimate) children ${ }^{37}$ and relations between adoptive parents and adopted children..$^{38}$

The right to family life implies not only the right of family members to live together, but also to develop interpersonal relationships, ${ }^{39}$ thus it can be established among family members who do not live in the same household. ${ }^{40}$ Furthermore, family life is not limited to social, cultural and moral relations, but also encompasses interests of the material kind (such as subsistence). ${ }^{41}$

\subsubsection{The concept of home and correspondence}

The Court's case-law is very extensive in respect of alleged breaches of private or family life, as opposed to a much smaller number of cases of alleged violation of home and correspondence. ${ }^{42}$ The notion of home is closely related to the concepts of private and family life, since term home usually suggests a physical space in which private and family life takes place. ${ }^{43}$ When determining whether something is considered a home within the meaning of the Article 8 of the Convention, it is observed whether there are circumstances that indicate a sufficient and continuous connection of a person with a particular space. ${ }^{44}$ However, the Article 8 protects not only physical space but also the unhindered enjoyment of a certain quality of life. ${ }^{45}$ Besides written and electronic form of correspond-

${ }^{34}$ Olsson v. Sweden, app.no. 10465/83, judgement of $24^{\text {th }}$ of March 1988, para. 72.

${ }^{35} K$. and T. v. Finland, app.no. 25702/94, app.no $12^{\text {th }}$ of July 2001, para. 173; Maslov v. Austria, app.no. 1683/03, judgement of $23^{\text {rd }}$ of June 2008, para. 82.

${ }^{36}$ T.P. and K.M. v. the United Kingdom, app.no. 28945/95, judgement of $10^{\text {th }}$ of May 2001, para. 71-72; Johansen v. Norway, app.no. 17383/90, judgement of $7^{\text {th }}$ of August 1996, para. 64; A.D. and O.D. v. the United Kingdom, app.no. 28680/06, judgement of $16^{\text {th }}$ March 2010, para. 93.

${ }^{37}$ Chavdarov v Bulgaria, app.no. 3465/03, judgement of $21^{\text {st }}$ of December 2010, para. 40.

${ }^{38}$ Pini and Others v. Romania, app.no. 78028/01 78030/01, judgement of $22^{\text {nd }}$ of June 2004, para. 148; Negrepontis-Giannisis v. Greece, app.no. 56759/08, judgement of $3^{\text {rd }}$ of May 2011, para. 55.

${ }^{39}$ Marckx v. Belgium, app.no. 6833/74, judgement of $13^{\text {th }}$ of June 1979, para. 31; Brauer v. Germany, app.no. 3545/04, judgement of $28^{\text {th }}$ of May 2009. para. 30-33; Moustaquim v. Belgium, app.no. 12313/86, judgement of $18^{\text {th }}$ of February 1991, para. 36 .

${ }^{40}$ Margaret and Roger Andersson v. Sweden, app.no. 12963/87, judgement of $25^{\text {th }}$ of February 1992, para. 72; Ivana Krstić, Tanasije Marinković, Evropsko pravo ljudskih prava, Council of Europe, Belgrade 2016, 184.

${ }^{41}$ Merger and Cros v. France, app.no. 68864/01, judgement of $22^{\text {nd }}$ of December 2004, para. 46.

${ }^{42}$ W. A. Schabas, 366.

${ }^{43}$ Moreno Gómez v. Spain, app.no. 4143/02, judgement of $16^{\text {th }}$ of November 2004, para. 53.

${ }^{44}$ Yevgeniy Zakharov v. Russia, app.no. 66610/10, judgement of $14^{\text {th }}$ of March 2017, para. 30

${ }^{45}$ Moreno Gómez v. Spain, app.no. 4143/02, judgement of $16^{\text {th }}$ of November 2004, para. 53. 
ence, ${ }^{46}$ the concept of correspondence also entails other ways of communication, such as telephone conversations. ${ }^{47}$

\subsection{Restrictions of the Article 8 of the Convention}

As beforementioned, the rights protected under the Article 8 of the Convention are not absolute but suffer certain limitations. Therefore, not every interference in enjoyment of the mentioned rights is considered a violation of the Article 8.48 When in doubt whether there was a violation of the Article 8, it should firstly be established whether the situation in question relates to one of the objects protected by the Article 8, that is, whether it can be established the existence of private life, family life, home or correspondence. ${ }^{49}$ If the Court answers this question in the affirmative, the second stage is to determine whether there was an interference with the right to their undisturbed enjoyment, and whether that interference was justified - whether it was in accordance with the law, had a legitimate aim and was necessary in a democratic society. ${ }^{50}$ With regard to the exceptions foreseen in the Paragraph 2 of the Article 8 of the Convention, the Court enforces restrictive approach, ${ }^{51}$ taking into account that the exceptions apply only for those purposes for which there were envisioned. ${ }^{52}$

\subsection{1. 'The accordance with the law' restriction}

Limitations of the Article 8 are allowed solely by means which have fundament in the basis of domestic legal system, that is, they have to be based on effective provisions of national regulations..$^{53}$ Accordingly, in each specific case it is necessary to determine the existence of a certain regulation, but also, if that regulation meats certain criteria established by the Court's case law. The Court has concluded that a provision considered to be a basis for the interference does

\footnotetext{
${ }^{46}$ Bărbulescu v. Romania, app.no. 61496/08, judgement of $5^{\text {th }}$ of September 2017, para. 72.

${ }^{47}$ Mirgadirov v. Azerbaijan and Turkey, app.no. 62775/14, judgement of $17^{\text {th }}$ of September 2020, para. 117

${ }^{48}$ W. A. Schabas, 367.

49 I. Roagna, 13.

${ }^{50}$ Kennedy v. The United Kingdom, app.no. 26839/05, judgement of $18^{\text {th }}$ of May 2010, para. 130.

${ }^{51}$ Sidiropoulos and others v. Greece app.no. 57/1997/841/1047, judgement of $10^{\text {th }}$ of July 1998, para. 38.

${ }^{52}$ European Convention for the Protection of Human Rights and Fundamental Freedoms, European Court of Human Rights, Council of Europe, 1950, Art. 18.

${ }^{3}$ Weber and Saravia v. Germany, app.no. 54934/00, judgment of $29^{\text {th }}$ of June 2006, para. 84; S. and Marper v. United Kingdom, app.no. 30562/04 и 30566/04, judgment of $4^{\text {th }}$ of December 2008, para. 95; Uzun v. Germany, app.no. 35623/05, judgment of $2^{\text {nd }}$ of September 2010, para. 60; Rotaru v. Romania, app.no. 28341/95, judgment of $4^{\text {th }}$ of May 2000, para. 52.
} 
not have to be in writing, but could be in an unwritten form, ${ }^{54}$ whereby the way in which that provision is interpreted and applied by national courts is taken into account. ${ }^{55}$ There is also a qualitative requirement a provision considered to be a basis for the interference should fulfil. Namely, provision should be accessible and foreseeable, ${ }^{56}$ precise in formulation, as well as predictable in terms of the consequences it envisages. ${ }^{57}$ Therefore, the regulation should be available in such a way that a citizen has an indication that the regulation is applied in the given circumstances and is aware of the consequences of not obliging to it, ${ }^{58}$ so that one can adjust its behavior. ${ }^{59}$ The regulation must be such to provide at least a minimum degree of legal protection against arbitrariness of interference by public authorities with the rights protected by the Article $8 .{ }^{60}$

\subsubsection{The legitimate purpose of an interference with the Article 8 of the Convention}

If the Court concludes that an interference was in the accordance with the law, it shall continue to determine whether the interference was consistent with any of the legitimate aims enumerated in the Paragraph 2 of the Article 8. Namely, the Court determines whether the interference was in the interest of national security, public safety or the economic well-being of the country, or whether its cause was to prevent a disorder or a crime, to protect health or morals, or to protect the rights and freedoms of others. ${ }^{61}$ Although, unlike other restrictive clauses contained in the Convention, Paragraph 2 of the Article 8 does not provide for public order as a legitimate aim, the grounds for legitimate interference are still set quite broadly. ${ }^{62}$

${ }^{54}$ Sanoma Uitgevers B.V.v. the Netherlands, app.no. 38224/03, judgement of $14^{\text {th }}$ of September 2010, para. 83

${ }_{55}$ W. A. Schabas, 404.

${ }^{56}$ Uzun v. Germany app.no. 35623/05, judgement of $2^{\text {nd }}$ of September 2010, para. 60; Shimovolos v. Russia, app.no. 30194/09, judgement of $21^{\text {st }}$ of June 2011, para. 70.

${ }^{57}$ Shimovolos v. Russia app.no. 30194/09, judgement of $21^{\text {st }}$ of June 2011, para. 68; Rotaru v. Romania, app.no. 28341/95, judgement of $4^{\text {th }}$ of May 2000, para. 52; Slivenko v. Latvia app.no. $48321 / 99$, judgement of $9^{\text {th }}$ of October 2003, para. 107 .

58 Silver and others $v$. the United Kingdom, app.no. 5947/72; 6205/73; 7052/75; 7061/75; $7107 / 75 ; 7113 / 75 ; 7136 / 75$, judgement of $25^{\text {th }}$ of March 1983, para. 88; Halford $v$. the United Kingdom, app.no. 20605/92, judgement of $25^{\text {th }}$ of June 1997, para. 49; Malone v. The United Kingdom, app. no. 8691/79, judgement of $2^{\text {nd }}$ of August 1984, para. 67; Rotaru v. Romania, app.no. 28341/95, judgement of $4^{\text {th }}$ of May 2000, para. 52 .

${ }^{59}$ Amann v. Switzerland, app.no. 27798/95, judgement of $16^{\text {th }}$ of February 2000, para. 56.

${ }^{60}$ Malone v. The United Kingdom, app.no. 8691/79, judgement of $2^{\text {nd }}$ of August 1984, para. 79; Olsson v. Sweden, app.no. 10465/83, judgement of $24^{\text {th }}$ of March 1988, para. 61.

${ }^{61}$ European Convention for the Protection of Human Rights and Fundamental Freedoms, European Court of Human Rights, Council of Europe, 1950, Art. 8, para. 2.

${ }^{62}$ Steven Greer, The European Convention on Human Rights: Achievements, Problems and Prospects, Cambridge University Press, Cambridge 2007, 258. 
For this reason, the condition of legitimacy is not considered to be of undue importance for determining a potential violation of the Article $8 .{ }^{63}$ Moreover, Court analyzes the existence of legitimate aims rather concisely ${ }^{64}$ and generally takes the view that the State acted to achieve them. ${ }^{65}$

\subsubsection{The necessity of the interference with the Article 8 of the Convention in a democratic society}

The last element the Court examines when determining the justification of state interference with the Article 8 of the Convention is the necessity of that interference in a democratic society. This element is considered to "the most subjective" one. ${ }^{66}$ An interference shall be considered necessary in a democratic society if it is a consequence of a pressing social need, ${ }^{67}$ in proportion to a legitimate aim, and if the reasons justifying it are "relevant and sufficient." ${ }^{8}$ The Court takes into account the margin of appreciation given to the member states, since it is primarily their obligation to ensure a fair balance between the interests of the individual and the community as a whole. ${ }^{69}$ If it finds that the same legitimate aim could have been achieved by a less severe and restrictive measure, the Court shall conclude that the member state did not ensure a fair balance between competing interests, that the interference was disproportionate, and that it was, therefore, not necessary in a democratic society. ${ }^{70}$

\section{ANALYSIS OF THE COURT'S 2019 CASE LAW IN RESPECT OF THE ARTICLE 8 OF THE CONVENTION}

In the year of 2019, the Court rendered one hundred and one judgment establishing the existence of the violations of the Article 8 of the Convention, which judgments

${ }^{63}$ W. A. Schabas, 403.

${ }^{64}$ S.A.S. v. France, app. no. 43835/11, judgement of 1st of July 2014, para. 114.

${ }^{65}$ Interights, 2006, 43.

${ }^{66}$ W. A. Schabas, 406.

${ }^{67}$ Berrehab v. The Netherlands, app.no. 10730/84, judgement of $21^{\text {st }}$ of June 1988, para. 28; Silver and others $v$. the United Kingdom, app.no. 5947/72; 6205/73; 7052/75; 7061/75; 7107/75; $7113 / 75 ; 7136 / 75$, judgement of $25^{\text {th }}$ of March 1983, para. 97.

${ }^{68}$ Dudgeon v. the United Kingdom, app.no. 7525/76, judgement of $22^{\text {nd }}$ of October 1981, para. 52-53; Z v. Finland, app.no. 22009/93, judgement of $25^{\text {th }}$ of February 1997, para. 94.

${ }^{69}$ Berrehab v. The Netherlands, app.no. 10730/84, judgement of $21^{\text {st }}$ of June 1988, para. 28; Jevremović v. Serbia, app.no. 3150/05, judgement of $17^{\text {th }}$ of July 2007, para. 99; Keegan v. Ireland, app.no. 16969/90, judgement of $26^{\text {th }}$ of May 1994, para. 49; X, Y and $Z v$. the United Kingdom, app. no. 21830/93, judgement of $22^{\text {nd }}$ of April 1997, para. 41; Phinikaridou v. Cyprus, app.no. 23890/02, judgement of $20^{\text {th }}$ of December 2007, para. 47; Shofman v. Russia, app.no. 74826/01, judgement of $24^{\text {th }}$ of November 2005, para. 34.

${ }^{70}$ S. Greer, 259. 
shall be statistically presented below. Furthermore, the „key cases” shall be analyzed separately, since they are considered to be the cases in which the Court has made the decisions of the utmost importance. In the end, the sole case in which the Court rendered judgment in 2019 in connection with the Article 8 of the Convention, and in which the respondent state was the Republic of Serbia, shall be summarized.

\subsection{Statistical analysis of the cases in which it was determined whether there was violation of the Article 8 of the Convention and which were terminated by the Court's judgments in the year of 2019}

Chronologically, 31 cases began by applications filed in the first part of the $21^{\text {st }}$ century, ${ }^{71}$ while the other 70 applications were filed in the second part of the $21^{\text {st }}$ century. The oldest applications were filed in the year of $2006,{ }^{72}$ and the most recent ones in the year of $2018 .{ }^{73}$

\footnotetext{
${ }^{71}$ Simões Balbino v. Portugal, app.no. 11236/09, judgment of $29^{\text {th }}$ of January 2019; Izmestyev c. Russie, app.no. 74141/10, judgment of 27th of August 2019; Taşkaya and Ersoy v. Turkey, app.no. $72068 / 10$, judgment of $22^{\text {nd }}$ of January 2019; Krasnyuk $v$. Ukraine, app.no. 66217/10, judgment of $17^{\text {th }}$ of December 2019; Milovanović v. Serbia, app.no. 56065/10, judgment of $8^{\text {th }}$ of October 2019; E.B. v. Romania, app.no. 49089/10, judgment of $19^{\text {th }}$ of March 2019; Belyayev and others $v$. Ukraine, app. no. 34345/10, 50687/10, 70492/13 judgment of $6^{\text {th }}$ of June 2019; Bigun v. Ukraine, app.no. 30315/10, judgment of 21 $1^{\text {st }}$ of March 2019; Antonov and Others v. the Republic of Moldova and Russia, app.no. 315/10, 1153/10, 1158/10, judgment of $2^{\text {nd }}$ of July 2019; Savin v. Russia, app.no. 58811/09, judgment of $22^{\text {nd }}$ of January 2019; Mehmet Ulusoy and Others v. Turkey, app.no. 54969/09, judgment of $25^{\text {th }}$ of June 2019; Çapın v. Turkey, app.no. 44690/09, judgment of 15 $5^{\text {th }}$ of October 2019; Burgazly v. Ukraine, app.no. 41920/09, judgment of $21^{\text {st }}$ of March 2019; Avşar and Tekin v. Turkey, app.no. 19302/09, 49089/12, judgment of $17^{\text {th }}$ of September 2019; Zaykina $v$. Russia, app.no. 14620/09, judgment of $21^{\text {st }}$ of May 2019; Altay v. Turkey (no. 2), app.no. 11236/09, judgment of $9^{\text {th }}$ of April 2019; Blyudik v. Russia, app.no. 46401/08, judgment of $25^{\text {th }}$ of June 2019; Zhuravleva v. Ukraine, app.no. 45526/08, judgment of $31^{\text {st }}$ of January 2019; Leyla Can v. Turkey, app.no. 43140/08, judgment of $18^{\text {th }}$ of June 2019; Bykovtsev and Prachev v. Russia, app.no. 27728/08, 44353/08, judgment of $21^{\text {st }}$ of May 2019; Ryabinin and Shatalina v. Ukraine, app.no. 33006/07, judgment of 0 th of November 2019; Parmak and Bakır v. Turkey, app.no. 22429/07, 25195/07, judgment of $3^{\text {rd }}$ of December 2019; Roman v. The Republic of Moldova, app.no. 13274/07, judgment of $3^{\text {rd }}$ of December 2019; V.D. and Others v. Russia, app.no. 72931/10, judgment of $9^{\text {th }}$ of April 2019; Case of Abdyusheva and Others v. Russia, app.no. $58502 / 11,62964 / 10,55683 / 13$, judgment of $26^{\text {th }}$ of November 2019.; V.D. and Others v. Russia, app. no. 72931/10, judgment of $9^{\text {th }}$ of April 2019; Ecis v. Latvia, app.no. 12879/09, judgment of $10^{\text {th }}$ of January 2019; Aktaş and Aslaniskender v. Turkey, app.no. 18684/07, 21101/07, judgment of $25^{\text {th }}$ of June 2019; Yilmaz v. Turkey, app.no. 36607/06, judgment of 04 ${ }^{\text {th }}$ of June 2019; Gorlov and Others v. Russia, app.no. 27057/06, 56443/09, 25147/14, judgment of $2^{\text {nd }}$ of July 2019; Mityanin and Leonov v. Russia, app.no. 11436/06, 22912/06, judgment of $7^{\text {th }}$ of May 2019.

72 Mityanin and Leonov v. Russia, app.no. 11436/06, 22912/06, judgment of $7^{\text {th }}$ of May 2019; Yilmaz v. Turkey, app.no. 36607/06, judgment of $4^{\text {th }}$ of June 2019; Gorlov and Others v. Russia, app.no. 27057/06, 56443/09, 25147/14, judgment of $2^{\text {nd }}$ of July 2019.

${ }^{73}$ Bondar v. Ukraine, app.no. 7097/18, judgment of $17^{\text {th }}$ of December 2019; Ozdil and Others v. the Republic of Moldova, app.no. 42305/18, judgment of $11^{\text {th }}$ of June 2019; Lewit v. Austria, app. no. $4782 / 18$, judgment of $10^{\text {th }}$ of October 2019 .
} 
When it comes to respondent states, the greatest number of applications -24 in total -were filed against Russia, in time period from the year of 2006 to the year of $2017 .{ }^{74}$ After Russia comes Turkey with total of 12 applications filed before the Court. ${ }^{75}$ Ukraine is next, with 11 cases determining the existence of its violation of respect to private and family life. ${ }^{76}$ Then come Romania with seven applications

${ }^{74}$ Simões Balbino v. Portugal, app.no. 11236/09, judgment of $29^{\text {th }}$ of January 2019; Izmestyev c. Russie, app.no. 74141/10, judgment of 27. August 2019; Taşkaya and Ersoy v. Turkey, app.no. $72068 / 10$, judgment of $22^{\text {nd }}$ of January 2019; Krasnyuk v. Ukraine, app.no. 66217/10, judgment of $17^{\text {th }}$ of December 2019; Milovanović v. Serbia, app.no. 56065/10, judgment of $8^{\text {th }}$ of October 2019; E.B. v. Romania, app.no. 49089/10, judgment of $19^{\text {th }}$ of March 2019; Belyayev and others v. Ukraine, app.no. 34345/10, 50687/10, 70492/13 judgment of $6^{\text {th }}$ of June 2019; Bigun v. Ukraine, app.no. $30315 / 10$, judgment of 21 ${ }^{\text {st }}$ of March 2019; Antonov and Others v. the Republic of Moldova and Russia, app.no. 315/10, 1153/10, 1158/10, judgment of $2^{\text {nd }}$ of July 2019; Savin v. Russia, app.no. $58811 / 09$, judgment of $22^{\text {nd }}$ of January 2019; Mehmet Ulusoy and Others v. Turkey, app.no. 54969/09, judgment of $25^{\text {th }}$ of June 2019; Çapın v. Turkey, app.no. 44690/09, judgment of $15^{\text {th }}$ of October 2019; Burgazly v. Ukraine, app.no. 41920/09, judgment of 21 ${ }^{\text {st }}$ of March 2019; Avşar and Tekin v. Turkey, app.no. 19302/09, 49089/12, judgment of 17 $7^{\text {th }}$ September 2019; Zaykina v. Russia, app.no. 14620/09, judgment of $21^{\text {st }}$ of May 2019; Altay v. Turkey (no. 2), app.no. 11236/09, judgment of $9^{\text {th }}$ of April 2019; Blyudik v. Russia, app.no. 46401/08, judgment of $25^{\text {th }}$ of June 2019; Zhuravleva v. Ukraine, app.no. 45526/08, judgment of $31^{\text {st }}$ of January 2019; Leyla Can v. Turkey, app.no. 43140/08, judgment of $18^{\text {th }}$ of June 2019; Bykovtsev and Prachev v. Russia, app.no. 27728/08, 44353/08, judgment of $21^{\text {st }}$ of May 2019; Ryabinin and Shatalina $v$. Ukraine, app.no. 33006/07, judgment of $7^{\text {th }}$ of November 2019; Parmak and Bakır v. Turkey, app.no. 22429/07, 25195/07, judgment of $3^{\text {rd }}$ of December 2019; Roman v. The Republic of Moldova, app.no. 13274/07, judgment of $3^{\text {rd }}$ of December 2019; V.D. and Others v. Russia, app.no. 72931/10, judgment of $9^{\text {th }}$ of April 2019; Case of Abdyusheva and Others v. Russia, app.no. 58502/11, 62964/10, 55683/13, judgment of $26^{\text {th }}$ of November 2019; V.D. and Others v. Russia, app.no. 72931/10, judgment of $9^{\text {th }}$ of April 2019; Ecis v. Latvia, app.no. 12879/09, judgment of $10^{\text {th }}$ of January 2019; Aktaş and Aslaniskender v. Turkey, app.no. 18684/07, 21101/07, judgment of $25^{\text {th }}$ of June 2019; Yilmaz v. Turkey, app.no. 36607/06, judgment of $4^{\text {th }}$ of June 2019; Gorlov and Others v. Russia, app.no. 27057/06, 56443/09, 25147/14, judgment of $2^{\text {nd }}$ of July 2019; Mityanin and Leonov v. Russia, app.no. 11436/06, 22912/06, judgment of $7^{\text {th }}$ of May 2019.

${ }^{75}$ Kanal v. Turkey, app.no. 55303/12, judgment of $15^{\text {th }}$ of January 2019; Kirdök and Others v. Turkey, app.no. 14704/12, judgment of $3^{\text {rd }}$ of December 2019; Kavak c. Turkey, app.no. 30669/11, judgment of $7^{\text {th }}$ of May 2019; Taşkaya and Ersoy v. Turkey, app.no. 72068/10, judgment of $22^{\text {nd }}$ of January 2019; Mehmet Ulusoy and Others v. Turkey, app.no. 54969/09, judgment of $25^{\text {th }}$ of June 2019; Çapın v. Turkey, app.no. 44690/09, judgment of 15 th of October 2019; Avşar and Tekin v. Turkey, app.no. 19302/09, 49089/12, judgment of 17th of September 2019; Altay v. Turkey (no. 2), app.no. 11236/09, judgment of $9^{\text {th }}$ of April 2019; Leyla Can v. Turkey, app.no. 43140/08, judgment of $18^{\text {th }}$ of June 2019; Parmak and Bakır v. Turkey, app.no. 22429/07, 25195/07, judgment of $3^{\text {rd }}$ of December 2019; Aktaş and Aslaniskender v. Turkey, app.no. 18684/07, 21101/07, judgment of $25^{\text {th }}$ of June 2019; Yilmaz v. Turkey, app.no. 36607/06, judgment of 04 th of June 2019.

${ }^{76}$ Bondar v. Ukaine, app.no. 7097/18, judgment of $17^{\text {th }}$ of December 2019; Shvets v. Ukraine, app.no. 22208/17, judgment of $23^{\text {rd }}$ of July 2019; M.T. v. Ukraine, app.no. 950/17, judgment of $19^{\text {th }}$ of March 2019; Krasnyuk v. Ukraine, app.no. 66217/10, judgment of $17^{\text {th }}$ of December 2019; Belyayev and others $v$. Ukraine, app.no. 34345/10, 50687/10, 70492/13 judgment of $6^{\text {th }}$ of June 2019; Bigun v. Ukraine, app.no. 30315/10, judgment of 21 $1^{\text {st }}$ of March 2019; Burgazly v. Ukraine, app.no. 41920/09, judgment of $21^{\text {st }}$ of March 2019; Zhuravleva v. Ukraine, app.no. 45526/08, judgment of 31. January 2019; Ryabinin and Shatalina v. Ukraine, app.no. 33006/07, judgment of $07^{\text {th }}$ of November 2019; 
filed, ${ }^{77}$ Moldova with six applications filed ${ }^{78}$ and Norway with five applications filed. ${ }^{79}$ The total of four applications were filed against Italy ${ }^{80}$ and Croatia, ${ }^{81}$ the total of three applications against Lithuania, ${ }^{82}$ Bulgaria, ${ }^{83}$ and France, ${ }^{84}$ and the total of two applications against Spain, ${ }^{85}$ North Macedonia, ${ }^{86}$ the United Kingdom, ${ }^{87}$

Polyakh and Others v. Ukraine, app.no. 58812/15, 53217/16, 59099/16, 23231/18, 47749/18, judgment of $17^{\text {th }}$ of October 2019; Razvozzhayev v. Russia and Ukraine and Udaltsov v. Russia, app.no. $75734 / 12,2695 / 15,55325 / 15$, judgment of $19^{\text {th }}$ of November 2019.

${ }^{77}$ O.C.I. and Others v. Romania, app.no. 49450/17, judgment of 21. May 2019; Olindraru v. Romania, app.no. 1490/17, judgment of 9. April 2019; Solcan v. Romania, app.no. 32074/14, judgment of $8^{\text {th }}$ of October 2019; Stoian v. Romania, app.no. 289/14, judgment of 25. June 2019; Stroea v. Romania, app.no. 76969/11, judgment of 22. October 2019; E.B. v. Romania, app.no. 49089/10, judgment of $19^{\text {th }}$ of March 2019; Nicolae Virgiliu Tănase v. Romania, app.no. 41720/13, judgment of $25^{\text {th }}$ of June 2019.

${ }^{78}$ Pisică v. the Republic of Moldova, app.no. 23641/17, judgment of $29^{\text {th }}$ of October 2019; Bittoun v. Republic of Moldova, app.no. 51051/15, judgment of $5^{\text {th }}$ of March 2019; Iovcev and others v. Republic of Moldova and Russia, app.no. 40942/14, judgment of 17th of September 2019; Antonov and Others $v$. the Republic of Moldova and Russia, app.no. 315/10, 1153/10, 1158/10, judgment of $2^{\text {nd }}$ of July 2019; Roman v. The Republic of Moldova, app.no. 13274/07, judgment of $3^{\text {rd }}$ of December 2019; Ozdil and Others $v$. the Republic of Moldova, app.no. 42305/18, judgment of $11^{\text {th }}$ of June 2019.

${ }^{79}$ A.S. v. Norway, app.no. 60371/15, judgment of $17^{\text {th }}$ of December 2019; Abdi Ibrahim v. Norway, app.no. 15379/16, judgment of $17^{\text {th }}$ of December 2019; K.O. and V.M. v. Norway, app.no. $64808 / 16$, judgment of $19^{\text {th }}$ of November 2019; Høiness $v$. Norway, app.no. 43624/14, judgment of $19^{\text {th }}$ of March 2019; Strand Lobben and Others v. Norway, app.no. 37283/13, judgment of $10^{\text {th }}$ of September 2019.

${ }^{80}$ Luzi v. Italy, app.no. 48322/17, judgment of $5^{\text {th }}$ of December 2019; Narjis v. Italy, app.no. 57433/15, judgment of $14^{\text {th }}$ of February 2019; R.V. and Others v. Italy, app.no. 37748/13, judgment of $18^{\text {th }}$ of July 2019; Cordella and Others v. Italy, app.no. 54414/13, 54264/15, judgment of $24^{\text {th }}$ of January 2019.

${ }^{81}$ Bosak and others v. Croatia, app.no. 40429/14, judgment of $6^{\text {th }}$ of June 2019; Begović v. Croatia, app.no. 35810/14, judgment of $13^{\text {th }}$ of June 2019; $A$ and B v. Croatia, app.no. 7144/15, judgment of $20^{\text {th }}$ of June 2019; Adžić v. Croatia (no. 2), app.no. 19601/16, judgment of $2^{\text {nd }}$ of May 2019.

82 Širvinskas v. Lithuania, app.no. 21243/17, judgment of $23^{\text {rd }}$ of July 2019; Kosaité-Čypiene and Others v. Lithuania, app.no. 69489/12, judgment of $4^{\text {th }}$ of June 2019; Stankünaite v. Lithuania, app.no. 67068/11, judgment of $29^{\text {th }}$ of October 2019.

${ }^{83}$ Vetsev v. Bulgaria, app.no. 54558/15, judgment of $2^{\text {nd }}$ of May 2019; $X$ and Others $v$. Bulgaria, app.no. 22457/16, judgment of $17^{\text {th }}$ of January 2019; Ilieva v. Bulgaria, app.no. 22536/11, judgment of $12^{\text {th }}$ of December 2019.

${ }^{84}$ Halabi v. France, app.no. 66554/15, judgment of $16^{\text {th }}$ of May 2019; Guimon v. France, app. no. 48798/14, judgment of $11^{\text {th }}$ of April 2019; Lacombe v. France, app.no. 23941/14, judgment of $10^{\text {th }}$ of October 2019.

${ }^{85}$ Haddad v. Spain, app.no. 16572/17, judgment of $16^{\text {th }}$ of June 2019; López Ribalda and Others v. Spain, app.no. 1874/13, 8567/13, judgment of $17^{\text {th }}$ of October 2019.

${ }^{86} X v$. the former Yugoslav Republic of Macedonia, app.no. 29683/16, judgment of $17^{\text {th }}$ January 2019; Tasev v. North Macedonia, app.no. 9825/13, judgment of $16^{\text {th }}$ of May 2019; Until February of 2019, the official name of the state was the former Yugoslav Republic of Macedonia.

${ }^{87}$ Catt v. the United Kingdom, app.no. 43514/15, judgment of $24^{\text {th }}$ of January 2019; Beghal v. the United Kingdom, app.no. 4755/16, judgment of $28^{\text {th }}$ of February 2019. 
Austria ${ }^{88}$ Latvia $^{89}$ and Armenia. ${ }^{90}$ Sole application was filed against six countries - Slovakia, ${ }^{91}$ Switzerland,,${ }^{92}$ Malta, ${ }^{93}$ Germany, ${ }^{94}$ Hungary ${ }^{95}$ and Serbia. ${ }^{96}$

Bearing in mind objects protected by the Article 8, in total of 38 cases applicants claimed that their right to family life was violated, ${ }^{97}$ in total of 36 cases

${ }^{88}$ P.R. v. Austria, app.no. 200/15, judgment of $21^{\text {st }}$ of November 2019; Lewit v. Austria, app. no. $4782 / 18$, judgment of $10^{\text {th }}$ of October 2019 .

${ }^{89} \bar{E}$ cis v. Latvia, app.no. 12879/09, judgment of $10^{\text {th }}$ of January 2019; Andersena v. Latvia, app.no. 79441/17, judgment of $19^{\text {th }}$ of September 2019.

${ }^{90}$ Hambardzumyan v. Armenia, app.no. 43478/11, judgment of $5^{\text {th }}$ of December 2019; Case Of Nikolyan v. Armenia, app.no. 74438/14, judgment of $3^{\text {rd }}$ of October 2019.

${ }^{91}$ M.M.B. v. Slovakia, app.no. 6318/17, judgment of $26^{\text {th }}$ of November 2019.

${ }^{92}$ I.M. v. Switzerland, app.no. 23887/16, judgment of $9^{\text {th }}$ of April 2019.

${ }^{93}$ Mifsud v. Malta, app.no. 62257/15, judgment of $29^{\text {th }}$ of January 2019.

94 Wunderlich v. Germany, app.no. 18925/15, judgment of $10^{\text {th }}$ of January 2019.

${ }^{95}$ Szekeres and Others v. Hungary, app.no. 21763/14, judgment of $7^{\text {th }}$ of March 2019.

${ }^{96}$ Milovanović v. Serbia, app.no. 56065/10, judgment of $8^{\text {th }}$ of October 2019.

${ }^{97}$ A.S. v. Norway, app.no. 60371/15, judgment of $17^{\text {th }}$ of December 2019c Abdi Ibrahim v. Norway, app.no. 15379/16, judgment of 17th of December 2019; Bondar v. Ukraine, app.no. 7097/18, judgment of $17^{\text {th }}$ of December 2019; O.C.I. and Others v. Romania, app.no. 49450/17, judgment of 21. May 2019; Luzi v. Italy, app.no. 48322/17, judgment of 5. December 2019; Pisică v. the Republic of Moldova, app.no. 23641/17, judgment of 29. October 2019; Širvinskas v. Lithuania, app.no. $21243 / 17$, judgment of $23^{\text {rd }}$ of July 2019; Haddad v. Spain, app.no. 16572/17, judgment of $16^{\text {th }}$ of June 2019; Vladimir Ushakov v. Russia, app.no. 15122/17, judgment of $16^{\text {th }}$ of June 2019; Olindraru v. Romania, app.no. 1490/17, judgment of $9^{\text {th }}$ of April 2019; K.O. and V.M. v. Norway, app.no. 64808/16, judgment of $19^{\text {th }}$ of November 2019; Akopdzhanyan v. Russia, app.no. 32737/16, judgment of $1^{\text {st }}$ of October 2019; Bittoun v. Republic of Moldova, app.no. 51051/15, judgment of $5^{\text {th }}$ of March 2019; Wunderlich v. Germany, app.no. 18925/15, judgment of $10^{\text {th }}$ of January 2019; Zelikha Magomadova v. Russia, app.no. 58724/14, judgment of $8^{\text {th }}$ of October 2019; Begović v. Croatia, app.no. $35810 / 14$, judgment of $13^{\text {th }}$ of June 2019; Solcan v. Romania, app.no. 32074/14, judgment of $8^{\text {th }}$ of October 2019; Simões Balbino v. Portugal, app.no. 11236/09, judgment of $29^{\text {th }}$ of January 2019; Lacombe v. France, app.no. 23941/14, judgment of $10^{\text {th }}$ of October 2019; Rozhkani v. Russia, app. no. 14918/14, judgment of $9^{\text {th }}$ of July 2019; Szekeres and Others v. Hungary, app.no. 21763/14, judgment of $7^{\text {th }}$ of March 2019; Adžić v. Croatia (no. 2), app.no. 19601/16, judgment of $2^{\text {nd }}$ of May 2019; Andersena v. Latvia, app.no. 79441/17, judgment of $19^{\text {th }}$ of September 2019; R.V. and Others v. Italy, app.no. 37748/13, judgment of $18^{\text {th }}$ of July 2019; A.V. v. Slovenia, app.no. 878/13, judgment of $9^{\text {th }}$ of April 2019; Stankünaite v. Lithuania, app.no. 67068/11, judgment of $29^{\text {th }}$ of October 2019; Krasnyuk v. Ukraine, app.no. 66217/10, judgment of 17th of December 2019; Milovanović v. Serbia, app.no. 56065/10, judgment of $8^{\text {th }}$ of October 2019; Belyayev and others v. Ukraine, app.no. $34345 / 10,50687 / 10,70492 / 13$ judgment of $6^{\text {th }}$ of June 2019; Bigun v. Ukraine, app.no. 30315/10, judgment of $21^{\text {st }}$ of March 2019; Savin v. Russia, app.no. 58811/09, judgment of $22^{\text {nd }}$ of January 2019; Bykovtsev and Prachev v. Russia, app.no. 27728/08, 44353/08, judgment of $21^{\text {st }}$ of May 2019; Bogonosovy v. Russia, app.no. 38201/16, judgment of $5^{\text {th }}$ of March 2019; Razvozzhayev v. Russia and Ukraine and Udaltsov v. Russia, app.no. 75734/12, 2695/15, 55325/15, judgment of $19^{\text {th }}$ of November 2019; V.D. and Others v. Russia, app.no. 72931/10, judgment of $9^{\text {th }}$ of April 2019; $\bar{E} c i s$ v. Latvia, app.no. 12879/09, judgment of $10^{\text {th }}$ of January 2019; Strand Lobben and Others v. Norway, app.no. 37283/13, judgment of $10^{\text {th }}$ of September 201; Guimon v. France, app.no. 48798/14, judgment of $11^{\text {th }}$ of April 2019. 
applicants claimed that their right to private life was violated, ${ }^{98}$ in total of two cases applicants claimed that their right to correspondence was violated ${ }^{99}$ and in only one case an applicant claimed that their right to home was violated. ${ }^{100}$ In certain cases multiple violations of rights were observed at the same time. Hence, the Court was determining the violation of rights to private and family life in 14 cases, ${ }^{101}$

${ }^{98}$ M.M.B. v. Slovakia, app.no. 6318/17, judgment of $26^{\text {th }}$ of November 2019; M.T. v. Ukraine, app.no. 950/17, judgment of $19^{\text {th }}$ of March 2019; Xv. the former Yugoslav Republic of Macedonia, app.no. 29683/16, judgment of $17^{\text {th }}$ of January 2019; Narjis v. Italy, app.no. 57433/15, judgment of $14^{\text {th }}$ of February 2019; Catt v. the United Kingdom, app.no. 43514/15, judgment of $24^{\text {th }}$ of January 2019; Sidorova v. Russia, app.no. 35722/15, judgment of $28^{\text {th }}$ of May 2019; P.R. v. Austria, app.no. $200 / 15$, judgment of $21^{\text {st }}$ of November 2019; Stoian v. Romania, app.no. 289/14, judgment of $25^{\text {th }}$ of June 2019; $A$ and B v. Croatia, app.no. 7144/15, judgment of 20th June 2019; X and Others v. Bulgaria, app.no. 22457/16, judgment of $17^{\text {th }}$ of January 2019; Khadija Ismayilova $v$. Azerbaijan, app.no. 65286/13, 57270/14, judgment of $10^{\text {th }}$ of January 2019; Kosaite-Čypiene and Others $v$. Lithuania, app.no. 69489/12, judgment of $4^{\text {th }}$ of June 2019; Kanal v. Turkey, app.no. 55303/12, judgment of $15^{\text {th }}$ of January 2019; Stroea $v$. Romania, app.no. 76969/11, judgment of $22^{\text {nd }}$ of October 2019; Hambardzumyan v. Armenia, app.no. 43478/11, judgment of $5^{\text {th }}$ of December 2019; Kavak c. Turkey, app.no. 30669/11, judgment of $7^{\text {th }}$ of May 2019; Taşkaya and Ersoy v. Turkey, app.no. $72068 / 10$, judgment of $22^{\text {nd }}$ of January $2019 ;$ E.B. v. Romania, app.no. 49089/10, judgment of $19^{\text {th }}$ of March 2019; Mehmet Ulusoy and Others v. Turkey, app.no. 54969/09, judgment of $25^{\text {th }}$ of June 2019; Çapın v. Turkey, app.no. 44690/09, judgment of $15^{\text {th }}$ of October 2019; Parmak and Bakır v. Turkey, app.no. 22429/07, 25195/07, judgment of $3^{\text {rd }}$ of December 2019; Lewit v. Austria, app.no. 4782/18, judgment of $10^{\text {th }}$ of October 2019; Polyakh and Others v. Ukraine, app.no. 58812/15, 53217/16, $59099 / 16,23231 / 18,47749 / 18$, judgment of $17^{\text {th }}$ of October 2019; Case Of Nikolyan v. Armenia, app. no. 74438/14, judgment of $3^{\text {rd }}$ of October 2019; Cordella and Others v. Italy, app.no. 54414/13, 54264/15, judgment of $24^{\text {th }}$ of January 2019; Tasev v. North Macedonia, app.no. 9825/13, judgment of 16 ${ }^{\text {th }}$ of May 2019; Case of Abdyusheva and Others v. Russia, app.no. 58502/11, 62964/10, 55683/13, judgment of $26^{\text {th }}$ of November 2019; Gorlov and Others v. Russia, app.no. 27057/06, 56443/09, 25147/14, judgment of $2^{\text {nd }}$ of July 2019; Mityanin and Leonov v. Russia, app.no. 11436/06, 22912/06, judgment of $7^{\text {th }}$ of May 2019; Mifsud v. Malta, app.no. 62257/15, judgment of $29^{\text {th }}$ of January 2019; Yilmaz v. Turkey, app.no. 6p. 36607/06, judgment of $4^{\text {th }}$ of June 2019; Beghal v. the United Kingdom, app.no. 4755/16, judgment of $28^{\text {th }}$ of February 2019; Altay v. Turkey (no. 2), app.no. 11236/09, judgment of $9^{\text {th }}$ of April 2019; Nicolae Virgiliu Tănase v. Romania, app.no. 41720/13, judgment of $25^{\text {th }}$ June 2019; López Ribalda and Others v. Spain, app.no. 1874/13, 8567/13, judgment of $17^{\text {th }}$ of October 2019.

${ }^{99}$ Burgazly v. Ukraine, app.no. 41920/09, judgment of 21 ${ }^{\text {st }}$ of March 2019; Ryabinin and Shatalina v. Ukraine, app.no. 33006/07, judgment of $7^{\text {th }}$ of November 2019.

100 Zaykina v. Russia, app.no. 14620/09, judgment of 21 $1^{\text {st }}$ of May 2019.

${ }^{101}$ Zakharchuk v. Russia, app.no. 2967/12, judgment of 17th of December 2019; Shvets v. Ukraine, app.no. 22208/17, judgment of $23^{\text {rd }}$ of July 2019; I.M. v. Switzerland, app.no. 23887/16, judgment of $9^{\text {th }}$ of April 2019; Vetsev v. Bulgaria, app.no. 54558/15, judgment of $2^{\text {nd }}$ of May 2019; Goncharuk v. Russia, app.no. 58172/14, judgment of 27. August 2019; Yermakovich v. Russia, app. no. 35237/14, judgment of $28^{\text {th }}$ of May 2019; Romanov v. Russia, app.no. 76594/11, judgment of $29^{\text {th }}$ of July 2019; Izmestyev c. Russie, app.no. 74141/10, judgment of $27^{\text {th }}$ of August 2019; Antonov and Others v. the Republic of Moldova and Russia, app.no. 315/10,1153/10, 1158/10, judgment of $2^{\text {nd }}$ of July 2019; Avşar and Tekin v. Turkey, app.no. 19302/09, 49089/12, judgment of $17^{\text {th }}$ of September 2019; Leyla Can v. Turkey, app.no. 43140/08, judgment of $18^{\text {th }}$ of June 2019; Ozdil and Others v. 
the violation of rights to private life, family life and home in three cases, ${ }^{102}$ the violation of rights to private life and home in three cases, ${ }^{103}$ the violation of rights to private life and correspondence in two cases, ${ }^{104}$ the violation of rights to family life and correspondence in one case, ${ }^{105}$ and the violation of rights to correspondence and home in one case. ${ }^{106}$

It is important to state that the Court did not find a violation of the Article 8 in 21 cases, ${ }^{107}$ whereby one of those was specific - the violation was not determined only in relation to one applicant, while in relation to the rest of the applicants the application was declared inadmissible. ${ }^{108}$ Moreover, one case was considered wholly inadmissible on the basis of Article 35 of the Convention. ${ }^{109}$ In all the other cases, the Court found that there had been a violation of Article 8. However, in certain cases, violation was determined in respect of only one respondent state

the Republic of Moldova, app.no. 42305/18, judgment of 11 th of June 2019; Chaldayev v. Russia, app.no. 33172/16, judgment of $28^{\text {th }}$ of May 2019; Aktaş and Aslaniskender v. Turkey, app.no. 18684/07, 21101/07, judgment of $25^{\text {th }}$ of June 2019.

${ }^{102}$ Iovcev and others v. Republic of Moldova and Russia, app.no. 40942/14, judgment of $17^{\text {th }}$ of September 2019; Taziyeva and Others v. Russia, app.no. 32394/11, judgment of $9^{\text {th }}$ of April 2019; Roman v. The Republic of Moldova, app.no. 13274/07, judgment of $3^{\text {rd }}$ of December 2019.

${ }^{103}$ Halabi v. France, app.no. 66554/15, judgment of $16^{\text {th }}$ of May 2019; Zhuravleva v. Ukraine, app.no. 45526/08, judgment of $31^{\text {st }}$ of January 2019; Ilieva v. Bulgaria, app.no. 22536/11, judgment of $12^{\text {th }}$ of December 2019.

104 Bosak and others v. Croatia, app.no. 40429/14, judgment of $6^{\text {th }}$ of June 2019; Liblik and Others v. Estonia, app.no. 173/15, judgment of $28^{\text {th }}$ of May 2019.

${ }^{105}$ Blyudik v. Russia, app.no. 46401/08, judgment of $25^{\text {th }}$ of June 2019.

${ }^{106}$ Kirdök and Others v. Turkey, app.no. 14704/12, judgment of $3^{\text {rd }}$ of December 2019.

107 Zakharchuk v. Russia, app.no. 2967/12, judgment of $17^{\text {th }}$ of December 2019; K.O. and V.M. v. Norway, app.no. 64808/16, judgment of $19^{\text {th }}$ of November 2019; Mifsud v. Malta, app.no. $62257 / 15$, judgment of $29^{\text {th }}$ of January 2019; Narjis $v$. Italy, app.no. 57433/15, judgment of $14^{\text {th }}$ of February 2019; Wunderlich v. Germany, app.no. 18925/15, judgment of $10^{\text {th }}$ of January 2019; Guimon v. France, app.no. 48798/14, judgment of $11^{\text {th }}$ of April 2019; Høiness v. Norway, app.no. 43624/14, judgment of $19^{\text {th }}$ of March 2019; Simões Balbino v. Portugal, app.no. 11236/09, judgment of $29^{\text {th }}$ of January 2019; Lacombe v. France, app.no. 23941/14, judgment of $10^{\text {th }}$ of October 2019; Stoian v. Romania, app.no. 289/14, judgment of $25^{\text {th }}$ of June 2019; A and B v. Croatia, app.no. 7144/15, judgment of $20^{\text {th }}$ of June 2019; X and Others v. Bulgaria, app.no. 22457/16, judgment of $17^{\text {th }}$ of January 2019; Andersena v. Latvia, app.no. 79441/17, judgment of $19^{\text {th }}$ of September 2019; KosaitéČypiene and Others v. Lithuania, app.no. 69489/12, judgment of $4^{\text {th }}$ of June 2019; Stroea v. Romania, app.no. 76969/11, judgment of 22 nd of October 2019; Stankünaite v. Lithuania, app.no. 67068/11, judgment of $29^{\text {th }}$ of October 2019; Taziyeva and Others v. Russia, app.no. 32394/11, judgment of $9^{\text {th }}$ of April 2019; Case of Abdyusheva and Others v. Russia, app.no. 58502/11, 62964/10, 55683/13, judgment of $26^{\text {th }}$ of November 2019; Taşkaya and Ersoy v. Turkey, app.no. 72068/10, judgment of $22^{\text {nd }}$ of January 2019; López Ribalda and Others v. Spain, app.no. 1874/13, 8567/13, judgment of $17^{\text {th }}$ of October 2019; Mityanin and Leonov v. Russia, app.no. 11436/06, 22912/06, judgment of $7^{\text {th }}$ of May 2019.

108 Case of Abdyusheva and Others v. Russia, app.no. 58502/11, 62964/10, 55683/13, judgment of $26^{\text {th }}$ of November 2019.

${ }^{109}$ Nicolae Virgiliu Tănase v. Romania, app.no. 41720/13, judgment of $25^{\text {th }}$ June 2019. 
(while several states were respondents), ${ }_{110}$ in regards to only one applicant (while several persons submitted applications), ${ }^{111}$ in regards to only one object of protection (and the violation of several objects was being determined) ${ }^{112}$ or in relation to only one part of the described factual situation. ${ }^{113}$

From the total of hundred and one case in which it was being determined whether there was violation of Article 8 of the Convention and which were terminated by Court's judgments in the year of 2019, seven cases were declared as the Court's „key cases." 114 The Grand Chamber of the Court ruled in three of those seven cases. ${ }^{115}$ The Grand Chamber exclusively decides cases concerning matters important for interpretations and application of the Convention and cases concerning serious questions of general matter.

\subsection{The short review of "key cases"}

Five of seven „key cases” relate to the allegations of violations of the right to private life, while two relate to the violations of right to family life. In four cases the Court found the violation has occurred, in two cases no violation was found, while in one it was concluded that the Article 8 of the Convention was inapplicable ratione materiae.

\subsubsection{Misfud v. Malta ${ }^{116}$}

The applicant claimed there was a violation of his right to private life, as in paternity proceedings he had to provide a genetic sample contrary to his will. The

${ }^{110}$ Razvozzhayev v. Russia and Ukraine and Udaltsov v. Russia, app.no. 75734/12, 2695/15, 55325/15, judgment of $19^{\text {th }}$ of November 2019; Antonov and Others $v$. the Republic of Moldova and Russia, app.no. 315/10, 1153/10, 1158/10, judgment of $2^{\text {nd }}$ of July 2019; Iovcev and others $v$. Republic of Moldova and Russia, app.no. 40942/14, judgment of $17^{\text {th }}$ of September 2019.

111 Szekeres and Others v. Hungary, app.no. 21763/14, judgment of $7^{\text {th }}$ of March 2019; Razvozzhayev v. Russia and Ukraine and Udaltsov v. Russia, app.no. 75734/12, 2695/15, 55325/15, judgment of $19^{\text {th }}$ of November 2019.

112 Yermakovich v. Russia, app.no. 35237/14, judgment of $28^{\text {th }}$ May 2019.

${ }^{113}$ Bosak and others v. Croatia, app.no. 40429/14, judgment of $6^{\text {th }}$ of June 2019; V.D. and Others v. Russia, app.no. 72931/10, judgment of $9^{\text {th }}$ of April 2019.

${ }^{114}$ Mifsud v. Malta, app.no. 62257/15, judgment of $29^{\text {th }}$ of January 2019; Beghal v. the United Kingdom, app.no. 4755/16, judgment of $28^{\text {th }}$ of February 2019; Altay v. Turkey (no. 2), app.no. 11236/09, judgment of $9^{\text {th }}$ of April 2019; Nicolae Virgiliu Tănase v. Romania, app.no. 41720/13, judgment of $25^{\text {th }}$ of June 2019; Lopez Ribalda and Others $v$ Spain, app.no. 1874/13 8567/13, judgment of $17^{\text {th }}$ of October 2019; Strand Lobben and Others v. Norway, app.no. 37283/13, judgment of $10^{\text {th }}$ of September 2019; Guimon v France, app.no. 48798/14, judgment of $11^{\text {th }}$ of April 2019.

115 Nicolae Virgiliu Tănase v. Romania, app.no. 41720/13, judgment of $25^{\text {th }}$ of June 2019; Lopez Ribalda and Others $v$ Spain, app.no. 1874/13 8567/13, judgment of $17^{\text {th }}$ of October 2019; Strand Lobben and Others v. Norway, app.no. 37283/13, judgment of $10^{\text {th }}$ of September 2019.

${ }^{116}$ Mifsud v. Malta, app.no. 62257/15, judgment of $29^{\text {th }}$ of January 2019. 
Court concluded there was an interference in applicant's private life and thus began determining whether that interference was in accordance with the law, had a legitimate purpose and was necessary in a democratic society. After the Court confirmed that the interference was in accordance with the law, it approached the analysis of whether it had a legitimate purpose. It was concluded that the legitimate purpose existed - the protection of rights of others, specifically the protection of right of applicant's alleged daughter to collect information needed for the confirmation of her personal identity as a part of her private life. Moreover, the Court determined that the interference was necessary in a democratic society, as the domestic courts set a fair balance between the protection of the rights of the applicant's alleged daughter and the interest of the applicant not to provide the DNA sample. The violation of private life of the applicant was not determined.

\subsubsection{Beghal v. the United Kingdom ${ }^{117}$}

The applicant was stopped, questioned and searched at the United Kingdom airport under provisions of Schedule 7, which empowered police and immigration officers to stop, examine and search passengers without authorization or access to a lawyer - if there was a reasonable doubt of their involvement in terroristic activities. The applicant refused to answer most of the questions asked, for which reason she was subsequently convicted of intentionally failing to perform the duties provided for in Schedule 7. The applicant considered that her right to private life was violated and she filed an application to the Court. After determining that there was, indeed, interference in applicant's private life, the Court concluded this interference was not in accordance with law, since the provisions of the Article 8 were not sufficiently clear and predictable, and did not protect individuals against arbitrary interference by public authorities. Therefore, the Court found a violation of the Article 8 of the Convention.

\subsubsection{Altay v. Turkey (no. 2) $)^{118}$}

The applicant, a prisoner serving a life sentence, had received a package from his lawyer containing items such as a book and a newspaper. Concluding that the package did not contain materials related to the applicant's defense, the prison administration decided not to hand it over to the applicant. Furthermore, administration filed a request to the public prosecutor to initiate proceedings for an official to be present during consultations between the applicant and his lawyer. The domestic court granted the application, in an examination carried out solely on the basis of the case file, without holding a hearing and without seeking submissions from the

${ }^{117}$ Beghal v. the United Kingdom, app.no. 4755/16, judgment of $28^{\text {th }}$ of February 2019.

118 Altay v. Turkey (no. 2), app.no. 11236/09, judgment of $9^{\text {th }}$ of April 2019. 
applicant or his lawyer. The applicant claimed that his right to personal life was violated. The Court pointed out that a person's communication with his lawyer in the context of legal advice falls under notion of private life. Namely, due to the fact that the information exchanged is personal, intimate and sensitive in nature, the communication between an individual and his lawyer is reasonably expected to be private and confidential. Although the provisions of the applicable law were sufficiently precise, the domestic court did not interpret them in a right manner nor apply them correctly to the specific case. The applicable law clearly stated conditions under which the measure of supervising meetings between prisoner and his lawyer could be determined. However, sending a package not related to the defense was not listed among them. Consequently, the law was not foreseeable and the violation of the Article 8 occurred due to non-fulfillment of the conditions of legality.

\subsubsection{Nicolae Virgiliu Tănase v. Romania ${ }^{119}$}

The applicant was one of the four participants in the traffic accident, as a result of which he became disabled. The domestic authorities conducted an investigation which was eventually suspended, inter alia because there was a suspicion as to the existence of a causal link between the actions of one of the drivers and the injuries suffered by the applicant. The applicant lodged an application with the Court claiming that his rights under Articles 3, 6 and 13 of the Convention had been violated, but the Grand Chamber of the Court decided to examine the possible violation of the Articles 2 and 8 as well. Despite finding that the applicant had suffered severe physical injuries during the accident (and emphasizing that his body and physical integrity are both aspects of his private life protected by the Article 8 of the Convention), the Grand Chamber concluded that Article 8 was not applicable ratione materiae in the present case. The Grand Chamber based its decision on the findings that the injuries suffered by the applicant were due to the applicant's voluntary activities (driving a motor vehicle on a public road) and that they were not a result of an act aimed at violating the applicant's physical integrity. Thus, it was found that there was no human contact or interaction that could justify the application of the Article 8 of the Convention.

\subsubsection{Lopez Ribalda and Others $v \operatorname{Spain}^{120}$}

The applicants worked in a supermarket that had been sustaining economic losses. In order to investigate these losses, the employer of the applicants decided to install surveillance cameras. Some of the cameras were in plain sight while others were hidden. The applicants were notified of the presence of the cameras

${ }^{119}$ Nicolae Virgiliu Tănase v. Romania, app.no. 41720/13, judgment of $25^{\text {th }}$ of June 2019.

${ }^{120}$ Lopez Ribalda and Others v Spain, app.no. 1874/13 8567/13, judgment of $17^{\text {th }}$ of October 2019. 
that were visible, but not of those that were hidden. As the hidden camera footage proved they were stealing, the applicants were dismissed. Following the proceedings before the domestic courts, the applicants filled an application to the Court claiming that their right to respect for private life had been violated by secret video recording at their workplace. The Grand Chamber of the Court found that there had been no violation of the Article 8 of the Convention, concluding that the domestic courts had complied with their positive obligation under the Article 8, without going beyond their margin of appreciation. The domestic courts correctly found that the video surveillance measures were justifiably taken to meet a legitimate aim - protection of the employer's right to secure their property - and that they were appropriate and proportionate to that aim, which could not be achieved by less harmful measures.

\subsubsection{Strand Lobben and Others v. Norway ${ }^{121}$}

After the second applicant was born, the first applicant (the mother of the second applicant), voluntarily went to family center to receive help and guidance which she considered as needed at the time. Three weeks later, she withdrew her consent and wanted to leave the center together with her child. However, the child-protection services rejected her request, and decided to place the second applicant temporarily, and then permanently, in a foster family. After a certain period of time, the first applicant was deprived of her parental rights, and the second applicant was adopted by his previous guardians. Following domestic proceedings, the first applicant filled an application to the Court, holding that her and the second applicant's rights to family life had been violated. The Grand Chamber of the Court concluded that the decision-making process of the national authorities had not been carried out properly, as the severity of the interference with the applicants' family life was not proportionate to the applicants' interests, which were not adequately taken into account. The Grand Chamber emphasized that the procedure of determining parental capacities of the first applicant was not done thoroughly, especially in view of the fact that she had in the meantime got married and given birth to a second child. A violation of the right to respect for family life was established.

\subsubsection{Guimon v France $e^{122}$}

The applicant was serving a prison sentence for terrorist activities when she asked to temporarily leave the prison to attend her father's funeral. The domestic authorities determined that the death of her father was a reason that could justify permission for applicant to temporarily leave the prison, but they nevertheless

${ }^{121}$ Strand Lobben and Others v. Norway, app.no. 37283/13, judgment of $10^{\text {th }}$ of September 2019.

122 Guimon v France, app.no. 48798/14, judgment of $11^{\text {th }}$ of April 2019. 
rejected the request for logistical reasons. Namely, the applicant had submitted her request for prison leave promptly, leaving the authorities six days to make a decision and organize the escort. Once the final permission had been granted, there was no sufficient time to arrange specially trained escort and to organize the prior inspection of premises. The applicant filed the application to the Court claiming that her right to family life was violated by not allowing her to attend her father's funeral. The Court found that there was an interference in applicant's family life, but that this interference was in accordance with the law, was aimed at fulfilling legitimate goals - preservation of public safety and prevention of disorder or crimes - and was necessary in a democratic society. Therefore, there was no violation of the Article 8 of the Convention, since the state did not exceed its margin of appreciation, but has struck an appropriate balance between the applicant's right to respect for family life and the legitimate aims pursued.

\subsection{The Republic of Serbia as the respondent state}

Milovanović v. Serbia ${ }^{123}$ is the sole case in which the Court rendered judgment in 2019 in connection with the Article 8 of the Convention, and in which the respondent state was the Republic of Serbia. Although in a judgment of October 2005 the national court entrusted the applicant, as a mother, with the care and upbringing of her children and requested the immediate removal of the children from their father, this judgment was never enforced. The applicant filed an application to the Court stating that her right to family life was violated due to the omission of the domestic authorities to enforce appropriate measures, which resulted in depriving her of contact with her children and preventing her from exercising parental rights effectively. The Court pointed out that the Article 8 included the right of parents to be reunited with their children and the obligation of national authorities to carry out such reunification, bearing in mind the irreparable consequences that their relationship might otherwise suffer. The Court determined that the domestic authorities made numerous omissions to implement efficient measures, including coercive ones, to reunite the applicant and her children. Over time, the factual situation has changed to such an extent that the possibility of their reunification has been gradually destroyed. The Court concluded that there had been a violation of the applicant's right to family life.

\subsection{Conclusion remarks regarding the analyzed case law}

The analyzed case law suggests that the cases of allegations of violations of private life, family life, home and correspondence are quite heterogenous in terms of facts. The number of claims regarding the breach of respect to private and

${ }^{123}$ Milovanović v. Serbia, app.no. 56065/10, judgment of $8^{\text {th }}$ of October 2019. 
family life is almost equal, while claims regarding the violations of home and correspondence occur significantly less frequently. Violations of the rights protected under the Article 8 of the Convention have been found in four times the number in relation to the judgements in which it was decided that the violation did not occur. For that reason, it can be concluded that the respect of the Article 8 of the Convention is in a sort of a crisis. Nevertheless, it seems that the Court has so far managed to respond to the challenge posed, and to provide the necessary protection of private and family life as a last resort.

\section{THE CONCLUSION}

Bearing in mind that the Article 8 of the Convention protects the most intimate aspects of human life, the State should restrict the rights protected under the Article 8 exclusively in the manner by which the capacity of their enjoyment does not get severely affected. However, the analyzed case law suggests that the majority of the state members do not provide high threshold of the protection of the mentioned rights. Having in thought the current era of contemporary communication and digitalization, there is fear that the rights protected under the Article 8 of the Convention are becoming more endangered every day. The Court's 2019 "key cases" do not relate to the questions of the protection of private and family life, home and correspondence in the conditions of global technological progress, new means of communication, social networks and the Internet. Nevertheless, it is expected that precisely these questions will very soon give the new perspective of the rights under the Article 8, as well as provide the Court with new ways of determining the domain of their preservation.

\section{REFERENCES}

Books and Articles

William A. Schabas, The European Convention on Human Rights: A Commentary, Oxford University Press, Oxford 2016

Ivana Roagna, Protecting the right to respect for private and family life under the European Convention on Human Rights, Council of Europe human rights handbooks, Directorate General of Human Rights and Rule of Law Council of Europe, Strasbourg 2012

Jean-François Akandji Kombe, Positive obligations under the European Convention on Human Rights, Council of Europe Human Right Handbook Series No. 7, Belgium 2007

Steven Greer, The European Convention on Human Rights: Achievements, Problems and Prospects, Cambridge University Press, Cambridge 2007 
Loukēs G. Loukaidēs, The European Convention on Human Rights: Collected Essays, Martinus Nijhoff Publishers, Leiden 2007

Ivana Krstić, Tanasije Marinković, Evropsko pravo ljudskih prava, Council of Europe, Belgrade 2016

Legal acts

European Convention for the Protection of Human Rights and Fundamental Freedoms, European Court of Human Rights, Council of Europe, 1950, Art. 8.

Judgments of the European Court of Human Rights

P. and S. v. Poland, app.no. 57375/08, judgment of $30^{\text {th }}$ of October 2012.

Nunez v. Norway, app.no. 55597/09, judgment of $28^{\text {th }}$ of June 2011.

$X$ and $Y v$. the Netherlands, app.no. 8978/80, judgment of $26^{\text {th }}$ of March 1985.

Söderman v. Sweden, app.no. 5786/08, judgment of $12^{\text {th }}$ of November 2013.

Tavll v.Turkey, app.no. 11449/02, judgment of $9^{\text {th }}$ of November 2006.

Airey v. Ireland, app.no. 6289/73, judgment of $9^{\text {th }}$ of October 1979.

Dickson v. the United Kingdom, app.no. 44362/04, judgment of $4^{\text {th }}$ of December 2007.

Roche v. the United Kingdom, app.no. 32555/96, judgment of $19^{\text {th }}$ of October 2005.

Gaskin v. the United Kingdom, app.no. 10454/83, judgment of $7^{\text {th }}$ of July 1989.

Hämäläinen v. Finland, app.no. 37359/09, judgment of $16^{\text {th }}$ of July 2014.

Kennedy v. The United Kingdom, app.no. 26839/05, judgment of $18^{\text {th }}$ of May 2010,

Sidiropoulos and others v. Greece, app.no. 57/1997/841/1047, judgment of $10^{\text {th }}$ of July 1998.

Weber and Saravia v. Germany, app.no. 54934/00, judgment of $29^{\text {th }}$ of June 2006.

S. and Marper v. United Kingdom, app.no. 30562/04 и 30566/04, judgment of $4^{\text {th }}$ of December 2008.

Uzun v. Germany, app.no. 35623/05, judgment of $2^{\text {nd }}$ of September 2010.

Rotaru v. Romania, app.no. 28341/95, judgment of $4^{\text {th }}$ of May 2000.

Sanoma Uitgevers B.V. v. the Netherlands, app.no. 38224/03, judgment of $14^{\text {th }}$ of September 2010.

Shimovolos v. Russia, app.no. 30194/09, judgment of 21 $1^{\text {st }}$ of June 2011.

Slivenko v. Latvia, app.no. 48321/99, judgment of $9^{\text {th }}$ of October 2003.

Silver and others $v$. the United Kingdom, app.no. 5947/72, 6205/73, 7052/75, 7061/75, $7107 / 75,7113 / 75,7136 / 75$, judgment of $25^{\text {th }}$ of March 1983.

Halford v. the United Kingdom, app.no. 20605/92, judgment of 25 th of June 1997.

Malone v. the United Kingdom, app.no. 8691/79, judgment of $2^{\text {nd }}$ of August 1984.

Amann v. Switzerland, app.no. 27798/95, judgment of $16^{\text {th }}$ of February 2000.

Olsson v. Sweden, app.no. 10465/83, judgment of 24th of March 1988.

S.A.S. v. France, app.no. 43835/11, judgment of $1^{\text {st }}$ of July 2014.

Berrehab v. The Netherlands, app.no. 10730/84, judgment of 21 ${ }^{\text {st }}$ of June 1988.

Dudgeon v. the United Kingdom, app.no. 7525/76, judgment of 22 nd of October 1981. $Z$ v. Finland, app.no. 22009/93, judgment of $25^{\text {th }}$ of February 1997.

Jevremović v. Serbia, app.no. 3150/05, judgment of $17^{\text {th }}$ of July 2007.

Keegan v. Ireland, app.no. 16969/90, judgment of 26 th of May 1994.

$X, Y$ and $Z v$. the United Kingdom, app.no. 21830/93, judgment of 22 nd of April 1997. Phinikaridou v. Cyprus, app.no. 23890/02, judgment of $20^{\text {th }}$ of December 2007. 
Shofman v. Russia, app.no. 74826/01, judgment of $24^{\text {th }}$ of November 2005.

Costello-Roberts v. The United Kingdom, app.no. 13134/87, judgment of $25^{\text {th }}$ of March 1993.

Schuth v. Germany, app.no. 1620/03, judgment of 23 $3^{\text {rd }}$ of September 2010.

Fernandez Martinez v. Spain, app.no. 56030/07, judgment of $12^{\text {th }}$ of June 2014.

Nada v. Switzerland, app.no. 10593/08, judgment of 12 ${ }^{\text {th }}$ of September 2012.

Glor v. Switzerland, app.no. 13444/04, judgment of 30 ${ }^{\text {th }}$ of April 2009.

Tysiac v. Poland, app.no. 5410/03, judgment of 20th of March 2007.

Pretty v. the United Kingdom, app.no. 2346/02, judgment of 29th of April 2002.

Bensaid v. the United Kingdom, app.no. 44599/98, judgment of $6^{\text {th }}$ of February 2001. Bărbulescu v. Romania, app.no. 61496/08, judgment of $5^{\text {th }}$ of September 2017.

Denisov v. Ukraine, app.no. 76639/11, judgment of 25th of September 2018.

Jehovah's Witnesses of Moscow v. Russia, app.no. 302/02, judgment of $10^{\text {th }}$ of June 2010.

Gillberg v. Sweden, app.no. 41723/06, judgment of $3^{\text {rd }}$ of April 2012.

Haas v. Switzerland, app.no. 31322/07, judgment of $20^{\text {th }}$ of January 2011.

Niemietz v. Germany, app.no. 13710/88, judgment of 16 th $^{\text {th }}$ December 1992.

Sargsyan v. Azerbaijan, app.no. 40167/06, judgment of $16^{\text {th }}$ of June 2015.

E.S. v. Sweden, app.no. 5786/08, judgment of $21^{\text {st }}$ of June 2012.

Von Hannover v. Germany, app.no. 40660/08, 60641/08, judgment of $7^{\text {th }}$ of February 2012.

Y.F. v. Turkey, app.no. 24209/94, judgment of 22 $2^{\text {nd }}$ of July 2003.

Bigaeva v. Greece, app.no. 26713/05, judgment of $28^{\text {th }}$ of May 2009.

Sidabras and Džiautas v. Lithuania, app.no. 55480/00, 59330/00, judgment of $27^{\text {th }}$ of July 2004.

Negrepontis-Giannisis v. Greece, app.no. 56759/08, judgment of $3^{\text {rd }}$ of May 2011.

Znamenskaya v. Russia, app.no. 77785/01, judgment of $2^{\text {nd }}$ of June 2005.

Cierva Osorio de Moscoso and Others v. Spain, app.no. 41127/98, 41503/98, 41717/98, 45726/99, judgment of $28^{\text {th }}$ of October 1999.

Chapman v. the United Kingdom, app.no. 27238/95, judgment of $18^{\text {th }}$ of January 2001.

Ciubutaru v. Moldova, app.no. 27138/04, judgment of $27^{\text {th }}$ of April 2010.

Peck v. the United Kingdom, app.no. 44647/98, judgment of $28^{\text {th }}$ of January 2003.

Stübing v. Germany, app.no. 43547/08, judgment of 12 th of April 2012.

Alkaya v. Turkey, app.no. 42811/06, judgment of $9^{\text {th }}$ of October 2012.

Leander v. Sweden, app.no. 9248/81, judgment of 26 th of March 1987.

Khelili v. Switzerland, app.no. 16188/07, judgment of $18^{\text {th }}$ of October 2011.

M.M. v. the United Kingdom, app.no. 24029/07, judgment of $13^{\text {th }}$ of November 2012. Pfeifer v. Austria, app.no. 12556/03, judgment of $15^{\text {th }}$ of November 2007.

Chauvy and Others v. France, app.no. 64915/01, judgment of 29th of June 2004.

Gillan and Quinton v. the United Kingdom, app.no. 4158/05, judgment of $12^{\text {th }}$ of January 2010.

Moreno Gómez v. Spain, app.no. 4143/02, judgment of $16^{\text {th }}$ of November 2004.

Hatton and Others $v$. the United Kingdom, app.no. 36022/97, judgment of $8^{\text {th }}$ of July 2003.

Oluić v. Croatia, app.no. 61260/08, judgment of $20^{\text {th }}$ of May 2010.

Mileva and Others v. Bulgaria, app.no. 43449/02, 21475/04, judgment of $25^{\text {th }}$ of November 2010.

Dadouch v. Malta, app.no. 38816/07, judgment of 20 th of July 2010.

Rasmussen v. Denmark, app.no. 8777/79, judgment of $28^{\text {th }}$ of November 1984. 
A.H. and Others v. Russia, app.no. 6033/13, 8927/13, 10549/13, 12275/13, 23890/13, 26309/13, 27161/13, 29197/13, 32224/13, 32331/13, 32351/13, 32368/13, 37173/13, 38490/13, 42340/13, 42403/13, judgment of $17^{\text {th }}$ of January 2017. Marckx v. Belgium, app.no. 6833/74, judgment of $13^{\text {th }}$ of June 1979. Krušković v. Croatia, app.no. 46185/08, judgment of $21^{\text {st }}$ of June 2011. Kroon and Others v. the Netherlands, app.no. 18535/91, judgment of 27th of October 1994. K. and T. v. Finland, app.no. 25702/94, judgment of $12^{\text {th }}$ of July 2001. Popov v. France, app.no. 39472/07, 39474/07, judgment of $19^{\text {th }}$ of January 2012. Gluhaković v. Croatia, app.no. 21188/09, judgment of 12 ${ }^{\text {th }}$ of April 2011. Monory v. Romania and Hungary, app.no. 71099/01, judgment of $5^{\text {th }}$ of April 2005. Fuşcă v. Romania, app.no. 34630/07, judgment of $13^{\text {th }}$ of July 2010, para. 32. Maslov v. Austria, app.no. 1683/03, judgment of $23^{\text {rd }}$ of June 2008, para. 82. T.P. and K.M. v. the United Kingdom, app.no. 28945/95, judgment of $10^{\text {th }}$ of May 2001. Johansen v. Norway, app.no. 17383/90, judgment of $7^{\text {th }}$ of August 1996.

A.D. and O.D. v. the United Kingdom, app.no. 28680/06, judgment of $16^{\text {th }}$ of March 2010. Chavdarov v Bulgaria, app.no. 3465/03, judgment of $21^{\text {st }}$ of December 2010.

Pini and Others v. Romania, app.no. 78028/01 78030/01, judgment of $22^{\text {nd }}$ of June 2004. Abdulaziz, Cabales and Balkandali v. United Kingdom, app.no. 9214/80 9473/81 9474/81, judgment of $28^{\text {th }}$ of May 1985.

A.A. v. The United Kingdom, app.no. 8000/08, judgment of $20^{\text {th }}$ of September 2011. Mustafa and Armağan Akın v. Turkey, app.no. 4694/03, judgment of $6^{\text {th }}$ of April 2010. Bronda v. Italy, app.no. 22430/93, judgment of $9^{\text {th }}$ of June 1998.

Brauer v. Germany, app.no. 3545/04, judgment of 28. May 2009.

Moustaquim v. Belgium, app.no. 12313/86, judgment of $18^{\text {th }}$ of February 1991.

Margaret and Roger Andersson v. Sweden, app.no. 12963/87, judgment of $25^{\text {th }}$ of February 1992.

Merger and Cros v. France, app.no. 68864/01, judgment of 22 $2^{\text {nd }}$ of December 2004. Yevgeniy Zakharov v. Russia, app.no. 66610/10, judgment of 14 $4^{\text {th }}$ of March 2017. Mirgadirov v. Azerbaijan and Turkey, app.no. 62775/14, judgment of $17^{\text {th }}$ of September 2020.

Zakharchuk v. Russia, app.no. 2967/12, judgment of $17^{\text {th }}$ of December 2019. A.S. v. Norway, app.no. 60371/15, judgment of $17^{\text {th }}$ of December 2019. Abdi Ibrahim v. Norway, app.no. 15379/16, judgment of $17^{\text {th }}$ of December 2019. Bondar v. Ukraine, app.no. 7097/18, judgment of 17th of December 2019.

O.C.I. and Others v. Romania, app.no. 49450/17, judgment of $21^{\text {st }}$ of May 2019. Luzi v. Italy, app.no. 48322/17, judgment of $5^{\text {th }}$ of December 2019.

Pisică v. the Republic of Moldova, app.no. 23641/17, judgment of $29^{\text {th }}$ of October 2019. Shvets v. Ukraine, app.no. 22208/17, judgment of $23^{\text {rd }}$ of July 2019.

Širvinskas v. Lithuania, app.no. 21243/17, judgment of $23^{\text {rd }}$ of July 2019. Haddad v. Spain, app.no. 16572/17, judgment of $16^{\text {th }}$ of June 2019. Vladimir Ushakov v. Russia, app.no. 15122/17, judgment of $16^{\text {th }}$ of June 2019. M.M.B. v. Slovakia, app.no. 6318/17, judgment of $26^{\text {th }}$ of November 2019. Olindraru v. Romania, app.no. 1490/17, judgment of $9^{\text {th }}$ of April 2019. M.T. v. Ukraine, app.no. 950/17, judgment of $19^{\text {th }}$ of March 2019. K.O. and V.M. v. Norway, app.no.64808/16, judgment of $19^{\text {th }}$ of November 2019. Akopdzhanyan v. Russia, app.no.32737/16, judgment of $1^{\text {st }}$ of October 2019. 
$X v$. the former Yugoslav Republic of Macedonia, app.no.29683/16, judgment of $17^{\text {th }}$ of January 2019.

I.M. v. Switzerland, app.no. 23887/16, judgment of $9^{\text {th }}$ of April 2019. Mifsud v. Malta, app.no. 62257/15, judgment of 29th of January 2019. Narjis v. Italy, app.no. 57433/15, judgment of $14^{\text {th }}$ of February 2019. Vetsev v. Bulgaria, app.no. 54558/15, judgment of $2^{\text {nd }}$ of May 2019. Bittoun v. Republic of Moldova, app.no. 51051/15, judgment of $5^{\text {th }}$ of March 2019. Catt $v$. the United Kingdom, app.no.43514/15, judgment of $24^{\text {th }}$ of January 2019. Sidorova v. Russia, app.no.35722/15, judgment of $28^{\text {th }}$ of May 2019. Wunderlich v. Germany, app.no. 18925/15, judgment of $10^{\text {th }}$ of January 2019. P.R. v. Austria, app.no.200/15, judgment of $21^{\text {st }}$ of November 2019. Halabi v. France, app.no. 66554/15, judgment of $16^{\text {th }}$ of May 2019. Zelikha Magomadova v. Russia, app.no. 58724/14, judgment of $8^{\text {th }}$ of October 2019. Goncharuk v. Russia, app.no. 58172/14, judgment of $27^{\text {th }}$ of August 2019. Guimon v. France, app.no. 48798/14, judgment of 11 th of April 2019. Høiness v. Norway, app.no. 43624/14, judgment of $19^{\text {th }}$ of March 2019. Bosak and others v. Croatia, app.no.40429/14, judgment of $6^{\text {th }}$ of June 2019. Begović v. Croatia, app.no.35810/14, judgment of $13^{\text {th }}$ of June 2019. Solcan v. Romania, app.no.32074/14, judgment of $8^{\text {th }}$ of October 2019. Simões Balbino v. Portugal, app.no.11236/09, judgment of 29th of January 2019. Lacombe v. France, app.no. 23941/14, judgment of $10^{\text {th }}$ of October 2019. Rozhkani v. Russia, app.no.14918/14, judgment of $9^{\text {th }}$ of July 2019. Stoian v. Romania, app.no.289/14, judgment of 25th of June 2019.

Szekeres and Others v. Hungary, app.no.21763/14, judgment of $7^{\text {th }}$ of March 2019. Yermakovich v. Russia, app.no. 35237/14, judgment of $28^{\text {th }}$ of May 2019. Iovcev and others v. Republic of Moldova and Russia, app.no. 40942/14, judgment of $17^{\text {th }}$ of September 2019.

Liblik and Others v. Estonia, app.no. 173/15, judgment of $28^{\text {th }}$ of May 2019. $A$ and $B$ v. Croatia, app.no.7144/15, judgment of $20^{\text {th }}$ of June 2019. Adžić v. Croatia (no. 2), app.no.19601/16, judgment of $2^{\text {nd }}$ of. May 2019. $X$ and Others v. Bulgaria, app.no.22457/16, judgment of $17^{\text {th }}$ of January 2019. Andersena v. Latvia, app.no. 79441/17, judgment of $19^{\text {th }}$ of September 2019.

Khadija Ismayilova v. Azerbaijan, app.no.65286/13, 57270/14, judgment of $10^{\text {th }}$ of January 2019.

R.V. and Others v. Italy, app.no.37748/13, judgment of $18^{\text {th }}$ of July 2019. A.V. v. Slovenia, app.no.878/13, judgment of $9^{\text {th }}$ of April 2019.

Kosaite-Čypiene and Others v. Lithuania, app.no.69489/12, judgment of $4^{\text {th }}$ of June 2019. Kanal v. Turkey, app.no. 55303/12, judgment of $15^{\text {th }}$ of January 2019.

Kirdök and Others v. Turkey, app.no. 14704/12, judgment of $3^{\text {rd }}$ of December 2019.

Stroea v. Romania, app.no.76969/11, judgment of $22^{\text {nd }}$ of October 2019.

Romanov v. Russia, app.no.76594/11, judgment of 29th of July 2019.

Stankünaitè v. Lithuania, app.no. 67068/11, judgment of $29^{\text {th }}$ of October 2019. Hambardzumyan v. Armenia, app.no. 43478/11, judgment of $5^{\text {th }}$ of December 2019. Taziyeva and Others v. Russia, app.no.32394/11, judgment of $9^{\text {th }}$ of April 2019. Kavak c. Turkey, app.no.30669/11, judgment of $7^{\text {th }}$ of May 2019. Ilieva v. Bulgaria, app.no.22536/11, judgment of 12 ${ }^{\text {th }}$ of December 2019. 
Izmestyev c. Russie, app.no.74141/10, judgment of 27th of August 2019.

Taşkaya and Ersoy v. Turkey, app.no. 72068/10, judgment of $22^{\text {nd }}$ of January 2019.

Krasnyuk v. Ukraine, app.no. 66217/10, judgment of $17^{\text {th }}$ of December 2019.

Milovanović v. Serbia, app.no.56065/10, judgment of $8^{\text {th }}$ of October 2019.

E.B. v. Romania, app.no.49089/10, judgment of $19^{\text {th }}$ of March 2019.

Belyayev and others v. Ukraine, app.no.34345/10, 50687/10, 70492/13 judgment of $6^{\text {th }}$ of June 2019.

Bigun v. Ukraine, app.no. 30315/10, judgment of $21^{\text {st }}$ of March 2019.

Antonov and Others v. the Republic of Moldova and Russia, app.no.315/10, 1153/10, 1158/10, judgment of $2^{\text {nd }}$ of July 2019.

Savin v. Russia, app.no.58811/09, judgment of 22 nd of January 2019.

Mehmet Ulusoy and Others v. Turkey, app.no.54969/09, judgment of $25^{\text {th }}$ of June 2019. Çapin v. Turkey, app.no.44690/09, judgment of $15^{\text {th }}$ of October 2019.

Burgazly v. Ukraine, app.no. 41920/09, judgment of $21^{\text {st }}$ of March 2019.

Avşar and Tekin v. Turkey, app.no.19302/09, 49089/12, judgment of $17^{\text {th }}$ of September 2019.

Zaykina v. Russia, app.no.14620/09, judgment of $21^{\text {st }}$ of May 2019.

Altay v. Turkey (no. 2), app.no.11236/09, judgment of $9^{\text {th }}$ of April 2019.

Blyudik v. Russia, app.no.46401/08, judgment of $25^{\text {th }}$ of June 2019.

Zhuravleva v. Ukraine, app.no.45526/08, judgment of 31 st of January 2019.

Leyla Can v. Turkey, app.no. 43140/08, judgment of $18^{\text {th }}$ of June 2019.

Bykovtsev and Prachev v. Russia, app.no.27728/08, 44353/08, judgment of $21^{\text {st }}$ of May 2019.

Ryabinin and Shatalina v. Ukraine, app.no.33006/07, judgment of 0 $07^{\text {th }}$ of November 2019.

Parmak and Bakır v. Turkey, app.no.22429/07, 25195/07, judgment of $3^{\text {rd }}$ of December 2019.

Roman v. The Republic of Moldova, app.no.13274/07, judgment of $3^{\text {rd }}$ of December 2019.

Ozdil and Others $v$. the Republic of Moldova, app.no.42305/18, judgment of $11^{\text {th }}$ of June 2019.

Lewit v. Austria, app.no. 4782/18, judgment of $10^{\text {th }}$ of October 2019.

Bogonosovy v. Russia, app.no.38201/16, judgment of $5^{\text {th }}$ of March 2019.

Chaldayev v. Russia, app.no.33172/16, judgment of $28^{\text {th }}$ of May 2019.

Beghal v. the United Kingdom, app.no. 4755/16, judgment of 28 th of February 2019.

Polyakh and Others v. Ukraine, app.no.58812/15, 53217/16, 59099/16, 23231/18, $47749 / 18$, judgment of $17^{\text {th }}$ of October 2019.

Case Of Nikolyan v. Armenia, app.no.74438/14, judgment of $3^{\text {rd }}$ of October 2019.

Cordella and Others v. Italy, app.no.54414/13, 54264/15, judgment of $24^{\text {th }}$ of January 2019.

Nicolae Virgiliu Tănase v. Romania, app.no.41720/13, judgment of $25^{\text {th }}$ of June 2019.

Strand Lobben and Others v. Norway, app.no.37283/13, judgment of $10^{\text {th }}$ of September 2019.

Tasev v. North Macedonia, app.no. 9825/13, judgment of $16^{\text {th }}$ of May 2019.

López Ribalda and Others v. Spain, app.no.1874/13, 8567/13, judgment of $17^{\text {th }}$ of October 2019.

Razvozzhayev v. Russia and Ukraine and Udaltsov v. Russia, app.no.75734/12, 2695/15, $55325 / 15$, judgment of $19^{\text {th }}$ of November 2019. 
Case of Abdyusheva and Others v. Russia, app.no.58502/11, 62964/10, 55683/13, judgment of $26^{\text {th }}$ of November 2019.

V.D. and Others v. Russia, app.no.72931/10, judgment of $9^{\text {th }}$ of April 2019.

$\bar{E}$ cis v. Latvia, app.no.12879/09, judgment of $10^{\text {th }}$ of January 2019.

Aktaş and Aslaniskender v. Turkey, app.no. 18684/07, 21101/07, judgment of $25^{\text {th }}$ of June 2019.

Yilmaz v. Turkey, app.no. 36607/06, judgment of $4^{\text {th }}$ of June 2019.

Gorlov and Others v. Russia, app.no. 27057/06, 56443/09, 25147/14, judgment of $2^{\text {nd }}$ of July 2019.

Mityanin and Leonov v. Russia, app.no.11436/06, 22912/06, judgment of $7^{\text {th }}$ of May 2019. 


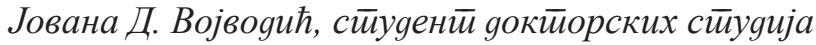

Универзииетеи у Новом Саgу

Правни факулиетеи у Новом Саgу

joja994ns@gmail.com

\section{Поштовање члана 8 Европске конвенције за заштиту људских права у новијој пракси Европског суда за људска права}

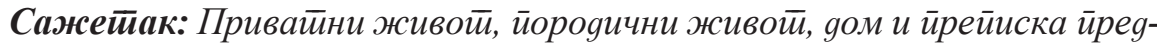

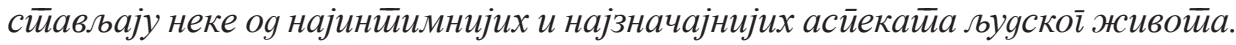

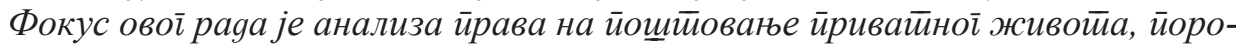

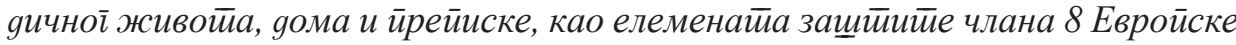
конвениије за зашитийу људских йрава и основних слобоgа. Анализа је сировеgена кроз истираживање и йумачење новије ирраксе Евройской суgа за љуgска иррава, йри чему је йосебан акиенай сйављен на случајеве о н највећеі значаја и Рейублику Србију као ииужену државу.

Кључне речи: Евройска конвенција за људска йрава, Евройски суд за

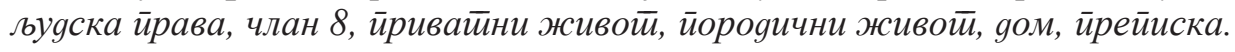

Датум пријема рада: 16.09.2020. 